\title{
Did the Old Left Get Due Process? The Case of Harry Bridgest
}

\author{
C.P. Larrowe*
}

"I personally want to say that I am appalled and ashamed," Kingman Brewster said on the eve of the May 1970 Black Panther trial in New Haven, "that things should have come to such a pass that I am skeptical of the ability of black revolutionaries to achieve a fair trial anywhere in the United States."1 Inevitably, the remark was viewed by some as an unwarranted slur on the judiciary. Nevertheless, it posed a disturbing question, coming as it did on the heels of a trial in Chicago that had made some wonder if a white militant could get a fair trial in an America convulsed by the divisions wrought by the Vietnam war. Moreover, the very basis for the conspiracy trial of the Chicago Eight and the demeanor of the presiding officer and other participants, were bleak reminders of the regularity with which, down through our history, civil liberties have eroded in times of crisis.

Indeed, even a casual stndent of the law must have been struck by the difference between the courtroom atmosphere in the usual criminal or civil proceeding and the aura of poitical trials such as those in Chicago and New Haven. The student must have been struck with how the customary rules of the game-for example, the courtesy opposing lawyers accord each other-are forgotten in a political trial; with how difficult it so often is for the judge in a pohitical trial to avoid succumbing to the prejudice of the inoment and to prevent his court froin becoming an arm of the executive branch; with how often attorneys for the defense end up being held in contempt; with how, as Aubrey Grossman lias aptly said, "A political trial produces a political verdict.".2

Such trials are not new to this country. They apparently occur during times of social and pohtical ferment as the natural result of serious challenge to the status quo. Thus, in the 1930 's, as the nation was passing through one of its most traumatic crises, we seemed on the

$\dagger$ This Article is drawn from material gathered for a book, Harry Bridges: The Rise and Fall of Radical Labor in the U.S., to be published later this year by Lawrence Hill \& Co., Westport, Connecticut.

* Professor of Economics, Michigau State Umiversity. B.A. 1946, M.A. 1948, University of Washington; Ph.D. 1952, Yale University.

1. May Day at Yale, Yale Alumni Magazine 17, 23 (May 1970).

2. Grossman, Lawyers on Trial, MASSES AND MANSTREAM, Aug. 1951, at 25. 
brink of a class war, with the CIO-to many, made in Moscow-organizing the troops. The political trial of this period came in 1938 with the Government's decision to deport Harry Bridges, ${ }^{3}$ the Australianborn leader of the west coast International Longshoremen's and Warehousemen's Union and a hero of the Old Left.

Bridges' troubles with the Government had their origins in the 1934 San Francisco general strike, ${ }^{4}$ when, as the spokesman for a longshoremen's rank-and-file strike committee, he announced to the press that the longshoremen had rejected an agreement negotiated by the conservative leadership of their union with the help of a federal mediator. The mediator described the longshoremen's action as the work of Communists, and it became the conventional wisdom in the press and in business circles that the strike was Communist-engineered and led. ${ }^{5}$ Because Bridges, an alien wlio talked and acted like a radical, emerged from the strike as a leading figure in west coast unionism, a violent protest against him began in San Francisco and quickly spread across the nation. ${ }^{6}$

Twenty years later, at the twilight of the McCarthy era, Bridges was still here, beginning his fourth prosecution on what was, in essence, the same charge: that lie had been a Communist in the thirties. His lawyer, this time Telford Taylor of New York, ${ }^{7}$ had come to the coast to meet with Bridges and his friend the late Paul St. Sure, then-president of the Pacific Maritime Association, to discuss defense strategy. Res judicata and double jeopardy were eliminated, because the first two "trials" liad really been administrative proceedings, and in the third the charge had been criminal conspiracy; this time it was civil conspiracy.

After an extended discussion of the issues, Taylor announced:

3. For a detailed account of how and why the decision was made, see notes $22-43$ infra and accompanying text.

4. C. LARROWE, LABOR History, pt. I, at 403-51, pt. II, at 3-37 (1970).

5. Id. pt. I, at 430 .

6. Id.; F. Perkins, The Roosevelt I KNew 316 (1946) [hereinafter cited as PeRkINS].

7. In his two deportation hearings (1939 and 1941) he was representcd by his San Francisco attorneys, Richard Gladstein and Aubrey Grossman, assisted by Carol King of New York [see note 58 infra]. His 1945 appeal to the U.S. Supreme Conrt was argued by Lee Pressman, general counsel of the CIO. On the brief with Pressman were Gladstein, Grossman, and King. Amicus briefs supporting Bridges were submittcd by the ACLU and the American Committee for the Protection of the Forcign Born.

Vincent Hallinan of San Francisco represented him in his 1950 criminal conspiracy trial [see text accompanying notes 195-96 infra]. His 1953 appeal to the Supreme Court was argued by Telford Taylor of New York, and Nonnan Leonard, a San Francisco partner of Richard Gladstein. John P. Frank, then a Yale law professor, helped write the brief. Taylor also represented him in his 1955 civil conspiracy trial in San Francisco [see notes 200-02 infra and accompanying text]. 
“OK. I've got a novel approach. I'll argue that Harry hasn't had due process because he's being tried again on the same charge he's been tried on three times before."

"Hell," Bridges retorted, "I don't deny that I've had due process.

I've had all the due process I want."

Indeed, from 1934 to 1955, due process had included several investigations by the San Francisco police, ${ }^{9}$ the Immigration Service, ${ }^{10}$ and the FBI; ${ }^{11}$ two bills in Congress, one of which passed, introduced for the explicit purpose of deporting him;12 two 10 -week administrative hearings before special Immigration Service examiners; ${ }^{13}$ one Immigration Appeals Board review; ${ }^{\mathbf{1 4}}$ one deportation order ${ }_{;}^{15}$ one criminal conspiracy trial to a jury, ${ }^{16}$ one civil conspiracy trial to a judge; ${ }^{17}$ at least seven lower and appellate court decisions; ${ }^{18}$ and three Supreme Court reprieves. $^{19}$

8. Interview with Paul St. Sure in San Francisco, July 24, 1963.

9. One investigation by San Francisco police is mentioned in a telegram sent during the 1934 west coast maritime strike by Edward Haff, San Francisco director of immigration, to Frances Perkins, Secretary of Labor. The telegram is in a file labelled NLRB Case No. 76, in the Roosevelt Memorial Library. Another is mentioned in an immigration mspector's report of a 1935 investigation of Communist charges against Bridges. The report is in the Perkins Papers, in the National Archives [hereinafter cited as Perkins Papers]. (At the time I looked at the papers, they had not been indexed.)

10. Perkins Papers, supra note 9.

11. For an account of one of Bridges' brushes with the FBI, see McKelway, Some Fun with the FBI, NEw YORKER, Oct. 11, 1941, at 59.

12. The first, introduced on May 14,1940, by Congressman Allen, a Louisiana Democrat, was H.R. 9766: "A bill to authorize the deportation of Harry Renton Bridges." H.R. 9766, 76th Cong., 3d Sess., 86 Cong. Rec. 6118 (1940). The one that passed was section 23 of the Alien Registration Act of 1940, 8 U.S.C. \$ 137(g) (1940) (conimonly known as the Smith Act, 54 Stat. 673). Congressman Hobbs of Alabama, who sponsored section 23, told the House on June 22: "It is my joy to announce that this bill will do, in a perfectly legal and constitutional manner, what the bill specifically aimed at the deportation of Harry Bridges seeks to accomplish." 86 CoNG. REC. 9031 (1940).

13. See James M. Landis, In the Matter of Harry Brddges: Findings and Conclusions of the Trial Examiner (1939) [hereinafter cited as Landis]; C. Sears, Memorandum of Decision in the Matter of Harry Renton Bridges, (1941) (Department of Justice) (mimeographed).

14. See Board of Immigration Appeals, In re: Harry Renton Bridges, 1942 (Department of Justice) (mimeographed).

15. F. Biddle, Harry Bridges Before the Atrorney General in Deportation HEARINGS, 1942.

16. United States v. Bridges, 90 F. Supp, 973 (N.D. Cal. 1950).

17. United States v. Bridges, 133 F, Supp. 638 (N.D. Cal. 1955).

18. Bridges v. United States, 199 F.2d 811 (9th Cir. 1952); Bridges v. United States, 184 F.2d 881 (9th Cir. 1950); Bridges v. Wixon, 144 F.2d 927 (9th Cir. 1944), rev'd, 326 U.S. 135 (1945); United States v. Bridges, 133 F. Supp. 638 (N.D. Cal. 1955); United States v. Bridges, 93 F. Supp. 989 (N.D. Cal. 1950); United States v. Bridges, 90 F. Supp. 973 (N.D. Cal. 1950); Ex parte Bridges, 49 F. Supp. 292 (N.D. Cal. 1943).

19. Each by a divided Court: Bridges v. United States, 346 U.S, 209 (1953) 
Bridges' remark was interesting for another reason. At the time he made it, he was on the threshold of a transformation in the public mind from the nation's number one union radical to an elder statesinan of organized labor. Shipowners, who for years had led the campaign to deport him, had come to see him as a constructive force in the industry, and several were even prepared to testify as character witnesses. Indeed, the day was not far off when he would be enshrined in collective bargaining textbooks as the architect of one of the most imaginative and successful schemes for removing barriers to technological progress. ${ }^{20}$

What follows is an account of Bridges' first, and biggest, "trial" -actually an administrative hearing - in what some have called the everlasting Bridges case. ${ }^{21}$

May 26, 1938, was an important day in the life of Harry Bridges, though he could scarcely have known it at the time. That was the day the House of Representatives created a committee to investigate unAmerican activities. ${ }^{22}$ Martin Dies, a Texas Deinocrat, was appointed chairman. ${ }^{23}$ Dies, who had a southerner's aversion to unions and to the social reforms of the New Deal, saw the committee as a handy club with which to beat the CIO and the Roosevelt Admimistration. His favorite Administration target was the Secretary of Labor, Frances Perkins, whom lie accused of coddling Communists-his favorite example being her failure to deport Harry Bridges. ${ }^{24}$

The committee had been in existence only a few months when Dies indicated that in view of the evidence his committee had in its files on Bridges, there inust be a conspiracy in the Labor Department to protect him. The matter came up in a cabinet meeting early in 1939, when the President asked Miss Perkins to review the facts of the Bridges case. "There was not a single one in the lot [that could] justify the ar-

(4-3); Bridges v. Wixon, 326 U.S. 135 (1945) (5-3); Bridges v. California, 314 U.S. 252 (1941) (5-4).

20. See, e.g., O. Phelps, INTRODUction to LABOR EConomics (3d ed. 1961); J. Healy, Creative Collective Bargaining (1965).

21. "The Everlasting Bridges Case" was the title of a pamphlet issued by his union on the eve of the 1955 civil conspiracy trial. United States v. Bridges, 133 F. Supp. 638 (N.D. Cal. 1955).

22. 83 CONG. REC. 7586 (1938). The vote was 191-44.

23. Id. at 8392 .

24. See 84 Cong. Rec. 702 (1939). See also Perkins 318-19; letter from United States District Judge for Massachusetts Charles E. Wyzanski, Jr., memorializing Miss Perkins' career, in N.Y. Times, May 19, 1965, at 46, col. 6 (city cd.). From 1933 to 1935, Judge Wyzanski was Solicitor of the U.S. Department of Labor. In 1938, supervision of immigration and deportation were functions of the Labor Department. 
bitrary expulsion of Bridges from the country."25 Nevertheless, when Miss Perkins finished, James A. Farley, Postmaster General and national chairman of the Democratic Party, pressed for deportation.

Whether Bridges was a Communist or not, the people of the country beheved that he was and believed that he ought to be deported. He declared that failure to deport him was doing great harm to the Democratic Party. In effect, he said that whether he was deportable or not, Bridges ought to be sent out of the country for the sake of the Democratic Party . . . . The President [however] made it clear that Bridges ought not to be deported unless there was legal justification for it. ${ }^{26}$

Bridges was safe for the moment, at least so far as the executive branch was concerned. But Dies and his committee kept pounding away at his The-New-Deal-is-soft-on-Communism theme, bringing it to a crescendo on January 24, 1939, with a resolution to impeach Secretary of Labor Perkins. ${ }^{27}$

"I didn't like the idea of being impeached and was considerably disturbed by the episode,"28 Frances Perkins has written. But Roosevelt made light of it, no doubt because he knew the resolution would die in the Judiciary Committee, which was safely in the hands of New Dealers. "It's all nonsense," he told Miss Perkins. ${ }^{29}$

\section{II}

In the beginning, when demands that Bridges be sent back to Australia first were made of Frances Perkins, it was "difficult to say whether the problem of deportation of Harry Bridges was a problem in industrial relations or a plam problem of justice."30 She had met

25. H. ICKes, The Secret DiARY of Harold L. ICKes 550 (1953). Ickes was FDR's maverick Republican Secretary of the Interior.

26. Id. When asked if le remembered making the statement attributed to him by Ickes, Farley replied: "Very frankly, I have no recollection of having made any such statement. I never kept records of Cabinet ineetings as I always considered those meetings to be very secretive in claaracter." Letter froin Jaines A. Farley to the author, Apr. $24,1962$.

27. 84 CONG. REc. 702 (1939).

28. PERKINS 319.

29. Id. On March 24, 1939, the House Judiciary Committee, headed by Dies' fellow Texan, Hatton W. Summers, unanimously rejected the Perkins impeachment resolution. H.R. REP. No. 311, 76th Cong., 1st Sess. 3273 (1939).

30. PERKINS 315.

In retrospect, it is plain that the desire to deport Harry Bridges lad httle to do with justice. As early as 1936, menbers of Congress were clamoring for Bridges' deportation without a shred of evidence to justify such a demand. In that year Daniel McCormack, then the Commissioner of Immigration, testified in answer to questions posed by Florence Kalın (conservative Congresswoman from California):

McCormack: The situation with reference to Bridges is this. He en-

tered the United States legally, and he lias a perfect right to be here.

Mrs. Kahn: He has never left the United States since? 
him once, briefly, in 1934, when she was in San Francisco for the AFL convention and Bridges had sent word he would like to see her.

I have a clear memory of him. He was a small, thin, somewhat haggard man im a much-worn overcoat, the collar turned up and pinned around his throat, with a cap in his hand. He was polite, deferential, hardly finding the voice to make demands for the striking longshoremen. His suggestions seemed practical and reasonable. I recall putting down im my mind that he was a typical British worker. ${ }^{31}$

On balance, the cry of "Communist!" that went up against Bridges looked to Secretary Perkins like a transparent employer tactic in the freeswinging industrial warfare of the thirties; both the witnesses and the evidence against him seemed highly questionable. San Francisco immigration officers reported to her that there was no evidence to show that he was connected with the Communist Party or any other radical organization. ${ }^{32}$

It was Secretary Perkin's practice, when someone wrote her that he knew Bridges was a Communist, to ask him to send documentary evidence or an affidavit. For three years, none was forthcoming. Then, in the fall of 1937, two immigration officials on the west coast applied for a warrant for Bridges' arrest and deportation, supporting it with affidavits of four men who said they had seen Bridges participate in Communist Party activities. They also sent along a photostatic copy of a C.P. membership card issued to one Harry Dorgan, implying

McCormack: He may have left since but if he has he had a perfect right to come back, because he has a legal status in the United States. Now, he has been accused of being a Communist, and we have been accused of permitting him to remain in spite of his beiug a Communist.

Mrs. Kahn: Yes, I know.

McCormack: The facts are, however, that there is no shred of evidence in our files on Bridges, or in the files of the San Fraucisco police department, to indicate that he is in any way subject to the provisions of the immigration law because of his radical views.

Mrs. Kahn: There must be something wrong.

McCormack: The San Francisco police department has followed him unremittingly for years, and our meu have also. He either is not a Communist or he has so carefully guarded his utterances that there is no legal ground for his deportation.

Testimony of Daniel W. McCormack before a subcominittee of the House Committee on Appropriations, 74th Cong., 2d Sess. 92, Feb. 28, 1936.

31. PERKINS 316.

32. Id. One of the investigators' discoveries amused FDR when she discussed the case privately with him. They had been told by the landlady of a boarding house where Bridges had hived in the early twenties that he was quiet, orderly, worked regularly, and paid his rent promptly. "What did he do in the evenings?" they asked. "I don't know much about that," she replied, "Mostly he went to his room after supper and played his mandolin until bedtime." Over the years, when the Bridges case came up in the newspapers, the President would ask Miss Perkins with a chuckle, "How's your mandolin player getting on?' Id. at 318. 
that Harry Dorgan was Bridges' name in the Party ${ }^{33}$ (Bridges' mother's maiden name was Dorgan).

The request put Frances Perkins in a quandary. For one thing, none of the affidavits corroborated the others, and she recognized one of the signers as a man with a notorious reputation for antilabor activity. Secondly, the request didn't come from San Francisco, where Bridges lived, but from Raphael Bonham and Roy Norene, wlio headed the Seattle and Portland immigration offices. Immigration officials in San Francisco reported that they still had no evidence sufficient to initiate deportation proceedings. ${ }^{34}$

Suspecting that Bonham and Norene inight have been taken im by their informants, Perkins sent Gerard Reilly, her general counsel, to the coast to investigate. Herbert Mills, one of the four men lined up by Bonham and Norene for Reilly to interview, was a member of the sailors' union goon squad. Laurence Milner, the second, was a major in the Oregon National Guard engaged in labor espionage. Not much was known about the third, John Leech, and Larry Doyle, the fourth, had rounded up the other three. Nevertheless, no doubt infected by Bonham's and Norene's enthusiasin for the case, Reilly reported back to Washington that the four would be effective witnesses. ${ }^{35}$

Perkins still hesitated, however: "I recognized that this was no ordinary deportation case, since the man was an important labor leader with whom settlements and bargaims were being carried on constantly."36 But the matter had already progressed too far.

Early in February, Bridges wrote Secretary Perkins, saying he was aware that immigration authorities were considering holding a deportation hearing and he assumed that he would be entitled to a bill of particulars. ${ }^{37}$ She wrote him that a hearing in his case was under study and that if the department decided to go ahead with it, he would of course get a statement of the specific charges against him. ${ }^{38}$

But, a few days later Reilly appeared in a closed session of Senator Royal S. Copeland's Commerce Committee, ${ }^{39}$ and Bridges decided

33. Id. at 317 .

34. Memorandum prepared by Secretary Perkins, in respouse to a letter from Congresswoman Mary Norton on Jan. 19, 1939, requesting a statement about the Bridges case, in the Perkins Papers.

35. Report of Gerard Reilly (1937) in the Perkins Papers.

36. PERKINs 317. She also asked Homer Cummings, the Attorney General, to check with J. Edgar Hoover as to what the FBI had on Bridges. Hoover answered, "The FBI has nothing in its files on Bridges." Memorandum from Brien McMahon, Assistant Attorney General, to Homer Cummings, Attorney General, Jan. 15, 1938, in the Perkins Papers.

37. Letter froin Bridges to Secretary Perkins, 1938, in the Perkins Papers. Papers.

38. Letter from Secretary Perkins to Harry Bridges, Feb. 1938, in the Perkins

39. Copeland, an old-line Deinocrat from New York, was delighted with Reilly's 
that to wait until Secretary Perkins got around to setting a date for the hearing would give Copeland, Dies, and Thomas time to inflame the pubhic against him. Thus, he wired Perkins on February 11, asking her to schedule the hearing immediately, before his congressional critics convicted him in the newspapers. ${ }^{40}$ She agreed, and on March 5, he and Lee Pressman, CIO general counsel, went by prearrangement to the immigration office in Baltimore, where a warrant for Bridges' arrest and deportation was served.

The four charges in the warrant were scarcely the bill of particulars Bridges had asked for. They were, first, that after entering the country, he became a member of an organization that believes $\mathrm{m}$, advises, advocates, and teaches the overthrow by force and violence of the Government of the United States; second, that after entering the country he became affiliated with such an organization; third, that after entering the country he became a member of an organization that causes to be written and circulated printed matter advising the overthrow by force and violence of the Government; and fourth, that after entermg the country he became affiliated with such an organization. ${ }^{41}$ The hearing was set for April 25, 1938, in San Francisco. ${ }^{42}$

When more than a month had gone by after the warrant for his arrest was served on him in Baltimore and the bill of particulars still hadn't come from Washington, Bridges sent Miss Perkins a formal request for it. He reminded her that in order to prepare his defense he needed to know the name of the organization referred to in the warrant; the date he was alleged to have becoine a member; the place where he was believed to have joined; the written documents, if any, tending to prove his membership; the naanner in which the Government claimed he became affiliated with the organization; and the printed matter advising the overthrow of the Government which the organization pubhshed and distributed.

The request did him no good: the Labor Department, worried because soine of its witnesses were beginning to have second thoughts about testifying, decided that its case would be endangered if it gave Bridges their names, or if it answered his other questions. All the Government would tell him was: "This organization . . . is the

testimony; it confirmed what he had told his colleagues in a Senate speech at the time of the 1936 maritime strikes. "There is in this country one Harry Bridges, an alien, who is here by our courtesy, who is an avowed Commumist and leader of a movement on the Pacific Coast, which in my opinion, is subversive and dangerous to our Government." 81 CoNG. REC. 3936 (1937).

40. Telegram from Harry Bridges to Secretary Perkins, Feb. 11, 1938, in the Perkins Papers.

41. See LaNDis, supra note 13 , at 1 .

42. See H.R. ReP. No. 311, 76th Cong., 1st Sess. 5 (1939). 
Communist Party of the U.S.A." ${ }^{43}$

III

Both sides were frantically preparing for the April 25 deadline when, with less than three weeks to go, a federal court of appeals reversed a deportation order against an admitted former Communist, Joseph Strecker. ${ }^{44}$ Strecker, a small self-employed merchant, had come to the United States from Poland in 1912, for sonie reason never applying for naturalization. Then, in 1932, with the country wallowing rudderlessly through the Depression and both major parties seemingly incapable of getting the economy on course again, he joined the Communist Party as a gesture of support for William Z. Foster, who was running for President on the Communist ticket, even though as an alien he could not vote. Strecker paid dues for three and a half months, then forgot about the Party. Later, in 1933, he decided to file for citizenship, innocently telling the immigration officer at the first interview about his brief encounter with the Party. That was when his troubles began. The officer reported it to his superiors, and the deportation machinery started turning. In no time, the Government had Strecker processed for deportation. But Poland, then in the hands of a rightwing dictatorship, threw a monkey wrench into the immigration machinery by informing the U.S. that it wouldn't take him back. Reprieved by Poland's rejection, Strecker made arrangements for an appeal to the courts.

Immigration authorities won in the federal district court in New Orleans. But when Strecker appealed the decision, the Fifth Circuit ruled in his favor:

It seems . . . to be a kind of Pecksniffian righteousness, savoring strongly of hypocrisy and party bigotry, to assume and find that merely because Strecker joined the Communist Party of America, he is an advocate of, or belongs to, a party which advocates the overthrow by force and violence of the government of the United States. ${ }^{45}$

Strecker put the case against Bridges in a new light. If Party membership wasn't a ground for deportation, Labor Department officials reasoned, there wouldn't be much point in going alead with the April 25 hearing. Unless Strecker was reversed, the charges against Bridges, even if proved, had no legal significance. ${ }^{46}$ For two weeks,

43. See LANDIs, app. 1 , at 135 .

44. Strecker v. Kessler, 95 F.2d 976 (5th Cir. 1938); Strecker v. Kessler, 96 F.2d 1020 (5th Cir. 1938), aff'd, 307 U.S. 22 (1939).

45. $95 \mathrm{~F} .2 \mathrm{~d}$ at 978 .

46. Letter from Secretary Perkins to Congresswoman Mary Norton, Jan. 21, 1939, in 84 Cong. REc. 652-53 (1939). Rep. Norton read the letter into the record on Jan. 23, 1939, as part of a defense of Perkins against attacks by the Dies Committee. See text accompanying notes 23-29 supra. 
Secretary Perkins pondered what to do now about the Bridges hearing, finally deciding to postpone it until the Supreme Court acted on Strecker.

\section{IV}

From a civil liberties point of view, the Supreme Court's decision in Kessler v. Strecker ${ }^{47}$ was at once a victory and a defeat. The Court held that Strecker could stay in the country, saying that an alien who becomes a member of the Communist Party after entering the country "is not deportable on that ground if at the time of his arrest his membership has ceased." 48 But the Court did not rule directly on the question posed by the Fifth Circuit decision: Was the Communist Party dedicated to the overthrow of the Government? The implication of Strecker was clear enough, however. If Strecker had been a Party member on November 25, 1933, when the warrant was issued for his arrest, he would have been deportable. It followed that if the Government could prove that Bridges was a Communist in Marcl 1938, when the warrant was issued for his arrest, he would be deportable. The Labor Department now moved as fast as even Congressman Dies could have wanted. Strecker came down on April 17, 1939, and Bridges' hearing was set for July 10, 1939, at the immigration station on Angel Island in San Francisco Bay. ${ }^{49}$

Frances Perkins still faced two awkward questions: First, who should preside at the hearing? Second, would the hearing be open or closed?

It was suggested, that inasmuch as the ranking officers of the Department had already been smeared as being pro-Bridges, and the West Coast officials of the Service had been smeared as anti-Bridges, and that since the evidence in the case was highly conflicting and depended primarily upon the relative credibility of the witnesses already interviewed, it was highly desirable that a lawyer of distinction and ability, having no ties with any of the West Coast factions, and whose standing was such that his judgment would be beyond suspicion of possible influence by the Secretary, the Administration, or employee groups, be appointed to sit as trial examiner. ${ }^{50}$

The Secretary appointed James W. Landis, dean of the Harvard Law School. ${ }^{51}$

47. 307 U.S. 22 (1939).

48. Id. at 30.

49. See E. WARD, HARRY BRIDGES on TrIaL 19 (1940) [hereinafter cited as WARd].

50. Frances Perkins, internal Labor Department memorandum (1939) in the Perkins Papers.

51. Not quite 40, Landis already had behind him a distinguished record as legal scholar and public servant. The son of a Presbyterian minister, he was born in Tokyo, where he had lived until he was 13. In 1925, after Princeton, Harvard Law School, and a 
The job seemed made to order for Landis, a specialist in administrative law ${ }^{62}$ and author of a casebook in labor law. ${ }^{53}$ Best of all, the hearing was to begin in mid-July and was expected to be over in a month-six weeks at the inost-before fall term would begin at the law school. Landis later recalled:

I had a summer free. I didn't know much about Harry Bridges. I hardly knew who he was. But I made two conditions for taking that job. One was that whatever happened, my report would be public. The second was that I would have complete control over the courtroom in which the hearings were held. Nobody else would have the right, except myself, to admit people or not admit them . . . .54

The second question was whether the hearing would be open, as Bridges wanted, or closed, as the Government insisted. Every deportation hearing up to that time had been closed, but Landis partially opened this one by issuing passes to 18 newspaper reporters and several magazine writers. $^{55}$ Thus, Landis struck a compromise, even though

[a]s a matter of strict law no right even to any kind of an open hearing attaches to proceedings of this nature. Deportation has been held by the courts again and again to be a civil proceeding to which the requirements of the sixth amendment . . . calling for an open trial, do not apply. ${ }^{50}$

He also admitted representatives of the American Civil Liberties Union, the American Legion, the Associated Farmers, the International Labor Defense, and a few others with a serious interest in the proceedings.

\section{$\mathrm{V}$}

"In an atmosphere of uncertainty and excitement friends, strangers and bitter enemies gathered about the gangplank to the hittle ferry

year as a law clerk for Justice Brandeis, he joined the law faculty at Harvard. In 1933, he went to Washington as a New Deal brain-truster, from which he was appointed to the Federal Trade Commission. He went from there to the Securities and Exchange Commission, becoining its chairman in 1935. In 1937, he left the SEC to go back to Harvard as dean of the law school. Interview with Landis at Colnınbia University, Feb. 10, 1963. Everyone, even the Hearst newspapers, whose chief had a passionate aversion to New Dealers, agreed that in Landis, Secretary Perkins had found just the man to preside at Angel Island. See S.F. Chronicle, Aug. 31, 1963, at 1, col. 2; S.F. Examiner, July 10, 1939, at 1, col. 5, and 9, col. 2 . before.

52. His book, The Administrative Process (1938), had been published the year

53. J. LANDis, Cases on Labor Law (1934).

54. Interview with Landis at Columbia University, Feb. 10, 1963.

55. Id. at 138. Among the writers was Estolv Ward, who covered the hearing for the Bridges Defense Committee and later wrote a book on the proceedings. WARD, supra note 49. Ella Winter covered it for the Manchester Guardian. Donald Ogden Stewart took notes for a piece he hoped to publish in the New Yorker.

56. LANDIS 137. 
Angel 1sland at Pier 5 early in the morning of July 10." Dean Landis, the two dozen or so observers and reporters, Bridges, accompanied by his 14-year-old daughter, Betty, who stayed at his side for the duration of the trial, Bridges' youthful San Francisco attorneys, Richard Gladstein, Aubrey Grossman, and Carol King, one of the country's leading experts on deportation law and a distinguished civil liberties lawyer, ${ }^{58}$ were all on the dock.

Also, there were the four Government lawyers: Bonham and Norene froin the Northwest, A.J. Phelan of the San Francisco immigration office, and Thomas Shoemaker, ${ }^{50}$ sent froin Washington to act as chief prosecutor.

Landis opened the hearing at 10:30 a.m., using a yellow pencil to call for order. Shoemaker read the warrant, in effect making an opening statement for the Government, after which he called his first witness, Harry Bridges.

At this time, $I$ just wish to ask you but two questions. Are you an ahen?

\section{I am.}

Are you now a member of the Communist Party?

No.

Or have you at any time in the past been a member of the Communist Party?

No.

No further questions at this time. . . .

Carol King made the opening statement for the defense:

Since 1934 Harry Bridges has been a stormy petrel around whoin has raged such a storm as only the most violent labor struggles engender. He has become such a symbol of labor strength to certain employer groups that they have spent, and continue to spend, large sums of money to get rid of him . . . . ${ }^{61}$

She described the efforts of private investigator Harper Knowles to persuade Frances Perkins to deport Bridges, but when Perkins demanded proof, Knowles had been found wanting. So Knowles and his co-conspirators spread the word that they would pay generously for affi-

57. WARD 19.

58. King had participated in many of the nation's most celebrated political trials, including the defense of Sacco and Vanzetti, and the Scottsboro Boys. She had also defended Strecker.

59. "Shoemaker was a nice guy . . . . He wasn't mean or out to get Harry the way they were later." Interview with Aubrey Grossinan, one of Bridges' attorneys, in San Francisco, Apr. 8, 1967.

60. Official Report of Proceedings Before the Immigration and Naturalization Service of the Department of Labor, In re Harry Bridges-Deportation Hearing 11 [hereinafter cited as Angel Island Transcript].

61. Id. at 12 . 
davits against Bridges. They also approached several men facing prison terms, offering to fix their sentences if they would sign an affidavit placing Bridges in a Communist meeting. ${ }^{62}$ She continued:

We shall show that this blackmail was carried out with the active assistance of high public officials. The most prominent participants of this type are Captain Keegan, of the Portland police, Lieutenant 'Red' Hynes, of the Los Angeles police, Clarence Morrill, director of the California State Bureau of Criminal Identification, and Captain Odale, of the Portland Police Force.

This conspiracy needed and depended upon the cooperation of someone in the Immigration and Naturalization Service. We charge that R.P. Bonham . . . and his assistant, R.J. Norene, were also cogs in this complicated wheel. ${ }^{63}$

Miss King next discussed the crucial role of Larry Doyle ${ }^{64}$ who, she asserted, "has supported himself by this case for several years." She concluded her opening statement with a charge that may have have struck some of her audience as a lawyer's hyperbole: "[T] he witnesses against Bridges are felons or labor spies, or both, and their evidence is not credible. . . ."

\section{VI}

The Government's first witness was Major Laurence Milner, one of the four whose affidavits were the basis for Bridges' arrest. ${ }^{66}$ At the

62. Id.

63. Id. at 13 .

64. Doyle, one of the affiants against Bridges [supra note 35 and accompanying text], became to many the star of the hearing although he never testified. See notes 232-44 infra and accompanying text.

65. Angel Island Transcript 14. When asked how they prepared to cross-examine the government witnesses without knowing who they were, Aubrey Grossman, one of Bridges' attorneys, answered:

We decided we'd make up a list of all the people who might be used, and we'd prepare dossiers on them. We began by listing everyone who'd turned against Harry. So we went to him, and he gave us some names. Then we made up a list of people the government had something on. And here was where Harry's lousy judgment of people showed up. In one case after another, when we brought up a name he'd say, "Aw, c'mon, he'd never fink on me!" And then that guy would turn up as a witness against him.

Then we went to the Communist Party. "Give us a list of the people in the area you've kicked out in the last year," we asked them.

By the time we finished, we had a steamer trunk and two suitcases full of dossiers on possible witnesses. On top of that we had an extensive card file, with the names of all the possible witnesses cross-indexed. When the Government put somebody on the stand, we'd look him up in our card file and prepare our cross-examination on the spot. Of course, we missed some. We couldn't anticipate them all.

Interview with Aubrey Grossman, San Francisco, Apr. 8, 1967.

66. See note 35 supra and accompanying text. 
outset, Milner was impressive. ${ }^{67}$ He had been a special agent of the military intelligence unit of the Oregon National Guard from 1933 to June 1937, assigned to the investigation of subversive groups. $\mathrm{He}$ had posed as a Communist to get his information from the inside, gaining their confidence by appearing as a character witness for Dirk De Jonge, a Party member who, fortuitously for Milner, went on trial just as Milner was starting on his undercover career. ${ }^{08}$

After the De Jonge trial ${ }^{69}$ Milner presided at radical meetings, and on occasion acted as an agent provocateur of mob violence. Thus established as a super-militant radical, he was accepted as trustworthy by the Communists, who were only too glad to accept his offers to drive them to and froin ineetings in his seven-passenger car. ${ }^{70}$ It was in April 1935, after one such trip, that he learned Bridges was a Red. Milner had driven Bridges from Portland to Seattle, where Bridges was scheduled to speak. After the meeting, Milner and Bridges went to a restaurant with several others-all Communists, according to Milner. There, Milner testified, Harry Jackson (a Communist functionary in the Northwest) asked Bridges for his Party dues and Bridges gave Jackson $\$ 2.50$, saying he did not want a receipt.

Milner then offered two conversations he had had with Bridges as further evidence of his Communist affiliation. Once, when he and Bridges were looking at some American battleships, Bridges remarked, "We will see a day when we can sink those damn things because they are the enemy of the workers." And another time, Bridges described to him how waterfront goon squads beat up opponents of the Communist Party. ${ }^{71}$

Aubrey Grossman, spelled by Gladstem, cross-examined, his curiosity piqued by Milner's testimony in the De Jonge trial. He felt sure

67. "[M]iddle-aged, erect as a ramrod, hawk-nosed . . . he took the stand confidently. ..." WARD 27.

68. De Jonge was sentenced to eight years in state prison for violating the Oregon criminal syndicalisin act by helping to organize a protest meeting in Portland during the 1934 waterfront strike after police fired on the strikers, killing some of them and wounding others. In 1937 the Supreme Court overturned his conviction. De Jonge v. Oregon, 299 U.S. 353 (1937).

69. It was during the De Jonge trial that Milner first met Larry Doyle, who had been hired by the state of Oregon as a special prosecutor for that case. Doyle sought him out and tried to bribe him to change his testimony about De Jonge, but he didn't take to Doyle, so he refused. The next time he met Doyle was in 1937, when Doyle was helping Portland police plant a dictaphone in Bridges' room. Doyle invited him to collaborate in the project, but he declined. "T didn't like his set-up," he told the hearing, "[H]e drank too much, and you can't trust anybody that drinks. . . ." "Too much," Landis interjected dryly. Angel Island Transcript 143.

70. Milner carried off his Communist masquerade so well that the American Legion took away his Legion button, and his former friend, Detective William "Big Bill" Browne of the Portland police red squad, threatened to beat him up. LaNDIs 12-13.

71. Id. at 14 . 
that Milner, appearing as a character witness for De Jonge, would have told the court that De Jonge wasn't a Party member. Yet in this hearing, in answer to Shoemaker's questions on direct examination, Milner had said he had known De Jonge was a Communist four months before he testified for him in Portland. "Did you tell the complete truth in that case?" they asked. "Yes, yes, I did. . . . I told the truth in that case, and I'm telling the truth here," Milner insisted over and over. They sent a hurried call to Portland, asking that a transcript of the De Jonge trial be rushed down to San Francisco.

The transcript arrived at their office late that afternoon. They were right: Milner had testified he knew De Jonge well, and that he was not a Communist. The next morning, they confronted Milner with the transcript and he admitted he had hed, both in the De Jonge trial, and yesterday. "I considered it my duty as a military intelligence officer to do anything to gain my purpose without being disclosed." He did not explain, however, why he had also testified falsely at the present hearing.

Landis was disgusted $;^{73}$ Thursday morning, as the hearing opened, he told the attorneys for both sides that he was turning Milner's testimony over to the Solicitor of the Labor Department for possible perjury prosecution. Landis was not just perturbed by Milner's deliberate lying under oath, but mucl of what Milner testified to when Shoemaker was questioning him was shown to be inaccurate under cross-examination. His most incriminating testimony-Bridges' conversations with him and his payment of $\$ 2.50$ dues to Jackson in Seattle-was not corroborated by any other witness. Perhaps most exasperating was Milner's boast that in his four-year tour of duty as an undercover agent, he had written 77 detailed reports on Bridges' actions-he referred to them repeatedly while he testified-yet none of his reports mentioned either the dues paynent or the conversations about which he had testified.

John Leech, another of the four who had signed affidavits, was next on the stand. In appearance,$^{74}$ he was very unlike Milner; in nore important ways, Leech was very much the saine. He liad something to hide, he contradicted himself as he testified, and he perjured

72. Id. at $17-19$.

73. 'Milner's testimony in this proceeding is deserving of little if any, credence. He can best be dismissed as a self-confessed liar, a man who lias admittedly tried twiceonce successfully-to make falsehood parade as truth." Id. at 19.

74. Leech's garments so fascinated reporters at the hearing that they described him in detail: "[He] wore a light tan checkered suit brightened by an orange handkerchief in the breast pocket, and a mottled orange tie. A sinall pink rosebud was in his lapel and his socks were gray with a pink design. He wore tan slooes." S.F. News, July 12,1939 , at 4 , col. 5 . 
himself prior to the hearing by signing, under oath, two contradictory affidavits about Bridges. And, like Milner, he exasperated Dean Landis:

Leech was afflicted with verbal haemophilia. It seemed impossible for him ever to answer straight-forward questions simply. Much of this was equivocation following upon Leech's being caught in earlier misstatements; mucl of it flowed from a curious pretense to knowledge about totally irrelevant matters; much of it, however, sprang merely from a habit of using ten words where 1 would have sufficed. ${ }^{75}$

Leech had joined the Communist Party in 1931, was on the Party payroll as an organizer in southern California from 1934 to 1936, and was expelled in mid-April 1937. ${ }^{76}$ "I have never seen documentary proof such as membership cards or other written data stating that Harry Bridges is a member of the Party," he said in the affidavit he gave the Government (it was read to the hearing before he testified), "but it was my common knowledge that he was, and that his Party name was Rossi."77 Leech said lie first saw Bridges in a Communist meeting in San Francisco in January or February 1936; Bridges was introduced as Comrade Rossi, gave a report on the impending strike in the maritime industry, and left. The second closed Party meeting where Leech saw Bridges was in May 1936, again in San Francisco. The purpose of this meeting was to nominate someone from northern California for election to the Party's central committee. Bridges, under the name of Rossi, was nominated, and, according to Leech, elected at the national convention in New York a short time later. ${ }^{78}$

Later, still on direct examination by Shoemaker, Leech again went over his story of the May 1936 meeting. Only now he said the business of the meeting was to prepare the agenda for a state convention, making no reference to the Bridges nomination. Then, a few minutes later, still answering Shoemaker's questions, he said that the meeting had been held to decide on delegates to send to the national convention and he, Leech, was one who went. ${ }^{79}$

On cross-examination, Bridges' lawyers pressed Leech for an explanation of the differences between the affidavit given to Government officials (read at the start of his testimony) and another conflicting affidavit given to two Party officials and their attorney, the former

75. LANDIS $20 \mathrm{n} .47$.

76. Id. at $21 \mathrm{nn} .53-54$.

77. Id. at 22 .

78. Id. at 23 .

79. None of the other ex-Communists who testified mentioned that Bridges had ever been on the Party's central committee, and no documentary proof of Bridges' membership on it was presented. Id. at 23 n.62. 
proclaiming Bridges to be a Communist ${ }^{80}$ and the latter claiming no knowledge of Bridges' having any Communist affiliation. Leech explained that he had signed the Communist affidavit because he feared for the safety of his family if he refused. However, he also admitted that Doyle had promised him a new job and a new life in Oregon if he signed an affidavit for the Government. Up until then, Leech had been unemployed and subject to prosecution in California for welfare fraud. ${ }^{81}$

Thus, the first two witnesses whose affidavits had led to Bridges' arrest were of little value to the prosecution. The third, Mills, could not be located and never testified, ${ }^{82}$ and Doyle, in Minnesota when the hearing began, had thus far refused to coine to San Francisco. ${ }^{83}$ The prosecution needed stronger evidence.

Bridges' putative Communist Party membership card ${ }^{84}$ came up as the hearing started its second week. It turned out to be without probative value, for while it bore the signature of the secretary of the Party, the naine Harry Dorgan ${ }^{85}$ was typewritten. Landis ruled that he would accept it as an exhibit, but it would not be in evidence. ${ }^{86}$

To revive its foundering case, the Government next called Aaron Sapiro, a Los Angles lawyer. As he took the stand, Landis brightened; he recognized the witness: ${ }^{87}$

80. The affidavit given the Party officials is in LANDIS, app. V, at 145 .

81. Id. at 25-33; Angel Island Transcript 411-12. Before Leech had been expelled from the Communist Party, he was receiving weekly paychecks as a Communist Party organizer, and working for a roofing company, yet he told California relief authorities that he had no income, and accepted welfare. LANDIS 43-47.

82. LANDIS 53.

83. Id., app. III, at $140-42$.

84. See text accompanying note 33 supra.

85. See note 33 supra and accompanying text.

86. Angel Island Transcript 987-88.

87. Landis interview, supra note 54. Early in his career, Sapiro had won a legal victory over Henry Ford, who had been waging a virulent campaign of anti-Semitism in his newspaper, the Dearborn Independent. For seven years, letters of protest from Jews were either rudely acknowledged or unanswered. Ford also ignored a public protest signed by such distinguished Americans as ex-Presidents Wilson and Taft, Jane Addams, Arclibishop Carleton J.H. Hayes, and William Jennings Bryan. Then the Dearborn Independent made a mistake: it attacked Aaron Sapiro, describing him as a Jewish lawyer and promoter who fleeced his clients (members of farm marketing associations he was organizing across the country). Sapiro countered with a libel suit against Ford, asking a million dollars in damages.

Ford, represented by a battery of seven lawyers headed by Senator James Reed of Missouri, narrowly escaped what promised to be an adverse verdict when the judge declared a mistrial. The case was set for retrial, but before it was called, Ford settled out of court and gave Sapiro a public apology. Ford, never a man to do anything by half, went on to apologize to the Jewish people as a whole, assuring thein that never agam would he allow anti-Semitic material to come from his presses.

In the early 1930's, sinall business was a promising field for a man with Sapiro's combination of legal and organizing talents. He moved to New York and then to Chi- 
His name was Sapiro. He took the stand. I looked at him. I said to myself, "You don't know me, but I know you.

"I met you about 20 years ago in Felix Frankfurter's office, in Cambridge. I was introduced to you as being one of the leading lawyers who would handle the cooperative movenent in Michigan." Of course, I didn't say this but I was thinking this. Finally, I thought, I'll get something I can rely on.

His direct stuff wasn't good. Then they opened up on him in cross. The cross examination went substantially like this:

"Mr. Sapiro, were you a meinber of the New York bar?"

"Yes."

"Are you now a member of the New York bar?"

"No."

"Were you disbarred?"

"Yes."

"Disbarred for trying to influence a jury?"

"Yes."

Then they went on:

"Did you become a member of the bar of the Supreıne Court of Illinois?"

"Yes."

"And were you at one time indicted?"

"Yes."

"And was the indictment for racketeering under the antitrust act?"

"Yes."

It went on. "Were these some of your co-defendants?" and they went down the line, Al Capone, etc.

Then he went on to practice in Los Angeles and got involved in the same thing. The guy had just gone to pieces in twenty years. ${ }^{88}$

Sapiro had become imvolved with Bridges after moving west, where he represented half a dozen newly emerging maritime unions, among them the longshoremen's local in San Pedro. He got on well with other union officials but not with Bridges, who from the first distrusted Sapiro because of his indiscriminate name-dropping. ${ }^{80}$

cago, where he organized both sides of the bargaining table: on the one side, trade associations of merchants, laundry owners, cleaners and dyers, tailors, milk distributors, and movie theater operators; on the other, labor unions of the workers his association members employed. Sapiro's clients happened to be in precisely the fields where gangsterisin and labor racketeering were most often found in the post-Prohibition era, and in 1933 he was indicted in Chicago, along with officials of his trade associations and unions, for bombings, mayhem, and the like, employed to force holdouts into his organizatons. He and his codefendants were acquitted, but a year later, he and one of his clients were charged with attempting to influence a jury. The other man was sent to jail. Sapiro was luckier: his only penalty was being barred from further practice in the federal courts. Id. See generally LANDIS, app. III, at 140-42.

88. Landis interview, supra note 54.

89. Ironically, Sapiro acted as Bridges' attorney in December 1936, when Bridges 
Sapiro came to Bonham's attention as a possible witness in September 1937, when he wrote a long and bitter open letter to CIO president John L. Lewis. ${ }^{90}$ In it, Sapiro attacked Lewis for splitting the ranks of labor, particularly for letting Cominunists get into positions of influence in the CIO; Bridges was one of the Communist officers named.

On the stand, Sapiro pictured himself as a dedicated anti-Coinmunist, ${ }^{21}$ yet he claimed to be an intimate of Earl Browder, the head of the Communist Party; Roy Hudson, the Party's maritime specialist; and William Schneiderman, the chief Communist official on the coast. ${ }^{92}$ Sapiro testified that he encountered Browder in a restaurant in 1936 and complaimed to him of Bridges' tactics im the maritime industry, which, he said, were undermining his own efforts to build unity between the sailors and longshoremen. Browder replied, according to Sapiro, that Bridges was one of the hardest men to handle in the Party, but that he would order him to work with Sapiro. ${ }^{93}$ Hudson and Schneiderman, Sapiro added, confirmed what Browder had said. ${ }^{94}$

Superficially, Sapiro's statements appeared damaging; however, they were uncorroborated. Browder and the others could, of course, have been subpoenaed, asked if they had made the remarks, and subjected to cross-examination. But the Government dechined to call them, contending that if Bridges contested the truth of Sapiro's testimony, it was his responsibility to call them. ${ }^{95}$ Landis disagreed, characterizing the testimony as liearsay, not admissible even under the looser rules of administrative hearings; the defense was not required to call witnesses to rebut inadmissible testimony. ${ }^{96}$

Moreover, it was all too apparent that Sapiro was motivated by a deep enmity against Bridges. Landis observed, "Their mutual hate [was] so intense as almost to be visible." "97 Accordingly, in the end,

was involved in a traffic accident in Los Angeles. Bridges had been driving with another longshoreinan when an eight-year-old boy on a bicycle came hurtling out of nowhere and ran head-on into his car. The boy died almost instantly. With the police liolding Bridges while they investigated, officials of the San Pedro longshore local called their attorney, Sapiro, to help ont. The coroner's jury exonerated Bridges, finding the boy's death accidental and unavoidable. Sapiro claimed the credit for the jury's ruling, but so far as Bridges could see, Sapiro's legal aid had been useless. Moreover, because he had not anthorized Sapiro to act for him, he refused to pay the $\$ 1,000$ bill Sapiro sent for his services. LANDIS 77, 81-83.

90. Id.

91. Id. at 79.

92. Id. at 80 .

93. Id. at 79 .

94. Id. at 80 .

95. Id. at 81 .

96. Id.

97. Id. 
Landis decided that Sapiro's stories about Bridges were not believable. "[S]omething more than the word of a disbarred and repudiated attorney seems required to carry [the] burden of proof." "98

By the time the hearing was in the middle of its second week, newspapermen covering it began wondering when Larry Doyle was going to take the stand. They discovered that the Government had lost interest in having him testify, but that he had been subpoenaed at the request of Bridges' attorneys. Doyle himself was discovered by a reporter in Lamberton, Minnesota, where he now had a law office. He told the reporter that despite the peculiarity of being called by the defense, he was willing to appear and show that Bridges was a Communist and guilty of moral turpitude. ${ }^{90}$

It inust have been apparent to Shoemaker that the Government's case was suffering from a serious lack of credibility. The testimony of the next two witnesses was certainly believable; however, that of the first had no substance and that of the second was primarily hearsay of the worst possible kind.

William Howard, whom Bridges called "the first honest witness they've put on,"100 had been an officer of the west coast Marine Fireinen's Union until 1937. Howard testified that in 1936 he was talking with Bridges out on the sidewalk after one of the meetings of the maritime convention. Bridges warned him that certain delegates would be waving the red flag at him, telling him that Bridges was a Commie.

I says, "That is neither here nor there with me, Harry. I don't care what they say."

He says, "Maybe I am a Commie. If I am, I might be damn proud of it." 101

Shoemaker asked Howard whether anything had occurred at the following convention of the maritime federation that would have led him to believe Bridges was a Communist. Yes, there was one thing in particular. Bridges' introduction of a resolution that all the unions in the federation should join the CIO.

We [the marine firemen] had made a study of the ClO and we come to the conclusion that the CIO was a Communist-controlled organization .... We considered [Bridges' resolution] as a deliberate attempt of the Communist Party to dissolve the unity that we hold in the maritime federation. ${ }^{102}$

Eugene Detrich, the Government's next witness, was one of the

98. Id. at 87 .

99. S.F. Examiner, July 21,1939 , at 2, col. 2.

100. S.F. Chronicle, July 21,1939 , at 1 , col. 2.

101. LANDIS 97.

102. Id. at 98 . 
most interesting as well as one of the most colorful-as he entered the hearing room, he checked his revolver with the marshal at the door. He was living dangerously, he believed, for when San Francisco's 4,500 longshoremen went over to the CIO, he stayed behind with 37 others, holding the fort for the more conservative AFL. ${ }^{103}$ Indeed, at the time Detrich was testifying, he was on the AFL payroll as an organizer, with San Francisco as his territory. ${ }^{104}$

As Detrich testified, it became apparent that he thought Bridges was a Communist because he supported what Detrich saw as Communist causes: the Scottsboro Boys, anti-war resolutions, the CIO refusals to load scrap iron for Japan, and the Western Worker ( a Communist Party newspaper)..$^{105}$ In 1935, he recalled, the Western Worker asked the longshoremen to make a donation to the paper in the forn of a full-page ad. "Bridges got up before the membership and stated that we have got the Communists to thank for a lot of our conditions, and virtually running the strike in ' 34 , and it wouldn't hurt us to go ahead and contribute a bit to them."106 The members, he recalled, voted not to take the ad.

Detrich's most important testimony came when he recounted a conversation he said he had had with Bridges' wife, Agnes, in 1935 or 1936. Bridges was out of town, and Detrich, trying to locate him, called Agnes.

[H]is wife had a peeve on .... . She says, "I am going to show him up for what he is."

I said, "What is that?"

She says, "Well," she says, "I have got his book."

And I said, "What do you mean-his book?"

She said, "I have got his book in the Communist Party. Everybody on the waterfront don't beheve he is a Communist."

I said, "Aw, get off your foot, Aggie." I was calling her about meeting with Mr. Bridges, so I could talk to her that way.

She says, "Well," she had it, and she was going to flash it, give it to the world; she was going to call up one of the newspapers, I think, at that time and give it to them, she says.

I says, "You haven't got his book."

She says, "Yes, I have."

[Shoemaker continued the questioning.]

Did you have any interest in it at all?

None whatsoever. I naturally thought it was just a hittle war between he and his wife. They get these peeves on, you know. . . .

Was she telling you the truth or was she just talking?

103. Id. at 99.

104. Id. at 101.

105. Id. at 103-05.

106. Angel Island Transcript 1503-04. 

talking.

At that time I never gave it a thought. I thought she was just

Have you given it any thought since?

Yes; quite a bit. . . . I believe now that she did have it.

[Landis broke in.] I am just anxious to know the date. You say that was sometime in '35; and as I remember your testimony, you said you did not believe her statement?

I didn't. I never even give it a thought . . . . She was just a little mad at Harry, because other times I have called her up, too, and Harry had been out of town a day or two, and I get a snappy answer; she bawls him out. ${ }^{107}$

Several times during the hearing the newspapers commented on the calm, cool, aloof impersonality of both Bridges and Dean Landis in the face of the bitterness and emotionalism out on Angel Island. The strain was taking its toll internally, however, on Bridges, who liad to be excused to be treated for an ulcer. ${ }^{108}$ And James W. Engstrom ${ }^{100}$ proved too much for the nerves even of the imperturbable Landis, who finally ordered stricken from the record Engstrom's lengthy but irrelevant testimony on how he had seen the Communist Party use white girls as lures to entice black men into the party. ${ }^{110}$

However, up to this point, the Government's case liad suffered from the failure of its witnesses to corroborate each other on important points, and despite Engstrom's otherwise weak contribution, ${ }^{111}$ they

107. LaNDIS 100.

108. "They're good union ulcers," Bridges remarked. "I don't know if they're AFL or CrO, but the jurisdictional dispute they're putting on inside me certainly is a terrific one." S.F. Examiner, July 27, 1939, at 9, col. 3.

109. Theodore Stark, an unemployed worker from Bellingham, Washington, had followed Detrich. Stark told the hearing that in 1936 or so, he was at a meeting of a small group of Communists that was told by Morris Rapport, Party district organizer for the Northwest:

The way Comrade Bridges gets our literature on foreign boats is by dropping it down funnels, and putting it under the temporary floors longshoremen build in the holds when they're stowing cargo. When longshoremen in foreign ports unload the ships, they run onto our literature.

Bridges" attorneys asked Stark about the nature of the literature. "I was told by Rap, or Rapport, rather," he answered, "that it called upon the Chinese and Japanese to work against their miserable working conditions that they were being forced to work under in the Orient and to strive for better working conditions in general."

"Did the literature urge them to organize unions," Stark was asked. "Yes, it did." "Did it ask them to join the Communist Party?" "I couldn't say to that," Stark replied. "That wasn't discussed." Angel Island Transcript 1687.

110. See id. at 1946-89.

111. In addition to the testimony ordered stricken by Landis as a use of racism as proof that the Communist Party was subversive [see text accompanying note 110 supra], Engstrom testified that in 1936, Bridges had asked him to run for president of the maritime federation. Engstrom said he was sure he had Bridges' support because Bridges knew that Engstroin was a Party member who would thus be subject to Party discipline [LaNDIs 107]; Engstrom had joined the Party only after he had received promises from Party nember and sailor Walter Stack that he would receive such support if he 
finally had a witness who offered evidence for which the Government had two other witnesses. Engstrom testified that he attended a Communist fraction meeting with Bridges in Seattle during the 1936 strike. Bridges was there to address a mass meeting of maritime workers, after which, Engstrom recalled, a small group of Communists met on Magnolia Bluff at the lome of Howard Costigan, secretary of the leftist Washington Commonwealth Federation. Among those present, Engstrom said, were Costigan, Rapport, Harry Jackson, and Bridges. He couldn't remember who else was there or what subjects were discussed, but he was certain it was an important Communist policy ineeting. ${ }^{112}$

One of the corroborators, John Davis, was an ex-Communist and former officer of the Sailors' Union of the Pacific in Aberdeen, Washington, who had been convicted of embezzling $\$ 1,800$ of his local's money. ${ }^{113}$ He testified that besides himself and Bridges, there were about 20 others at the Magnolia Bluff meeting. He knew everyone there-except for a CIO woodworker they were all nuaritime workers-and they talked from 11 p.m. to $12: 30$ or so about union problems in the maritime and lumber industries. On cross-examination he remembered that Morris Rapport and Harry Jackson, two Communist officials, had also been there. He couldn't remember anything more about the meeting, except that Harry Jackson called it to order, and that coffee was served. ${ }^{114}$

joined. Angel Island Transcript 1992.

Bridges later explained his reasons for supporting Engstrom:

One of the big grievances raised by the leadership of [the maritime federation], and it is still raised today, was that the shore unions, that is, unions like longshoremen, were opposed to unions that go to sea, and that they had too much control over the maritime federation. Therefore, our strategy was to answer that by saying, "All right, we will elect a seagoing man as president and as secretary of the federation in order to keep it together . ...."

Engstrom was a compromise candidate. We never trusted him, and we knew his weaknesses. That happens in inter-union politics just like it happens in any other politics. We knew at the time he was a pie card-a person in trade unions circles who had got his eye on the job and the money in the job, more than the interests of the meinbership.

We knew that because he wanted the job he might not go along with one side entirely to hold the job and have the other side trying to throw him out. . . .

[Bridges was asked.] Did you know he was a Communist?

I was pretty sure he wasn't. I know now; he had admitted it. . . . It could have been the farthest thing that I would imagine at that time, that Engstrom would be a Communist; maybe not because of his actions, but because of the weak type of individual that he was.

ld. at 2916-19.

Landis himself took a dim view of Engstrom. "Engstrom left a convincing impression that he was not telling the truth. Indeed, it is [iny] conclusion that Engstrom was never a Commumist." LaNDis 110.

112. LaNDIs 108.

113. Id. at 111 .

114. Davis' mability-or unwillingness--to be specific exasperated the Government attorneys, who questioned him almost as closely as if he had been a witness for the 
Gordon Castor ${ }^{115}$ was the other witness called by the Government to corroborate Engstrom's account of the Magnoha Bluff meeting. He recalled that 15 or 16 people were there, but he could remember by name only Bridges, Rapport, Jackson, Davis, and Pilcher. He was practically certain, however, that Engstrom was not there. And, in contrast to Engstrom's belief that the meeting was held in Howard Costigan's home, Castor did not remember Costigan as even having been at the meeting. ${ }^{110}$

The confusion of Magnolia Bluff remained until weeks later, when the defense called Bruce Hannon to the stand. He told the hearing that the meeting took place at his house on Magnoha Bluff, not Costigan's, who was his neighbor. At the time, Hannon was an officer of the Seattle longshoremen's local. When Bridges came to Seattle for the strike meeting, Hannon and Henry Geary, another longshoreman, met him at the train, took him to his hotel, then to a radio station for a broadcast, then to dinner, and from there to the mass meeting. Afterward, he took Bridges to his home to relax. Several union officials and one or two of Hannon's neighbors dropped in and they sat around chatting while the wives of some of his quests played cards in the dining room. ${ }^{117}$ Like the others, though, he could not remember exactly who had been at his house that night. He remembered his mother, his two brothers, Henry Geary, and Matt Meehan, secretary of the longshoremen's union; but he could not recall whether Davis had been there, and he said he had never met Castor. He was positive neither Jackson nor Rapport was present. Pilcher might have been, but he wasn't sure. ${ }^{118}$

Bridges was surer of who was present than Hannon. He remembered the neeting as a social affair after the mass neeting, and that

defense. Landis put his reaction to Davis this way:

Davis' . . . testimony is intrinsically weak. Its vagueness gave the impression of a subdued sense of stress that is difficult to appreciate apart from the visual impression created by his demeanor on the stand. Even the record as it stands discloses a man testifymg to the minimum details necessary for the purpose, never going beyond to volunteer one item that would fill in with a background of realism the bare bones of his recital. His subsequent addition of Jackson and Rapport to the persons present at this meeting, two of the most prominent Communists in that region, at the time sounded suspicions. It appears in the same light as one reviews the whole of his testimony.

Id. at 121.

115. Castor was an ex-Party member as well as a former member of the CIO woodworkers. He claimed to have been forced out of the CIO because he refused to recruit for the Party after he had come to the conclusion "that [the C.P.] was a destructive force in the American labor movement and would destroy the American labor movement . . . ." Angel Island Transcript 2284.

116. LANDIS 114 .

117. Id. at 120 .

118. Id. 
Hannon, Meehan, Costigan, Davis, and Engstrom had been in the group. He could not remember ever having seen Castor, and he was positive Rapport was not present, because he distinctly remembered that the first meeting he had had with him was in April 1937, after Bridges became west coast director of the CIO. ${ }^{119}$

What was the affair on Magnolia Bluff? A top fraction meeting? Or was it the sort of gathering that naturally follows a public meeting, where a speaker's host takes him home for an hour or two, inviting friends in for casual conversation? Landis accepted Hannon's and Bridges' view that it was the latter. He ended his analysis with the observation:

That among this group Communists might be present is entirely plausible, but considering the established falseness of so much of the testimony presented in this connection, no conviction attends the atternpt to transform this social gathering into a top fraction ineeting. 120

Thus the Government's first piece of corroborated important testimony failed.

After Castor, the Government began to lay a foundation for its argument that the Communist Party did in fact teach and advocate the overthrow of the Government. Its next witnesses were two immigration officials. The first, from Seattle, brought with him a stack of books and pamphlets he had bought in a Communist bookstore there. ${ }^{121}$ The second had a boxful of publications he had picked up on a shopping tour of C.P. bookstores in the Bay Area. ${ }^{122}$ Bonham then asked permission to put more Marxist publications into evidence and produced a library that a Marxist theorist might have coveted. ${ }^{123}$ With the admission of this material into evidence, the Government had basically completed the presentation of its evidence against Bridges. Their

119. Id.

120. Id. at 122 .

121. Angel Island Transcript 1850.

122. Id. at 1863-96.

123. He had arranged the 39 books and pamphlets in five groupings: (a) Penetration of the Communist Party into Labor Unions and other Organizations so as to Control or Influence them in the Party's Revolutionary Aims (9 titles); (b) Advocacy of Force and Violence as Necessary to the Overthrow of the Government of the Umited States and to the Establishment of the Dictatorship of the Proletariat (13); (c) History of the Communist Party of the Soviet Union (7); (d) Superiority and Authority of the Communist International Over All Sections, Including the Communist Party of the United States of America (4); (e) Subterfuge, Deceit and Secrecy (6).

It has been pointed out by Government officials that if the decision in the Bridges case, based on the Government's evidence [a reference to Bonham's books], is to the effect that the Communist Party does plot bloody revolt, it will form the basis for the prosecution and deportation of 100,000 Communists in this Nation-and will form the groundwork, as well, for legal action against the Communist Party itself.

S.F. Examiner, July 31, 1939, at 9, col. 4. 
argument that Bridges was a Communist rested on what their witnesses from Milner through Castor had told the hearing, and that was the evidence on which the action was brought. Except for a few persons called to rebut defense witnesses and to argue that the Communist Party was plotting revolution, the Government had but one other witness: Bridges himself. ${ }^{124}$

\section{VII}

When the prosecution called Bridges, the hearing took a new tack. The Government now sought to show, by Bridges own testimony, that he was "affiliated with"125 the Communist Party. For it must have been apparent that the Government had struck out in its effort to prove he was a meinber.

Bridges took the stand looking, to reporters on the scene, "dapper as a young capitalist." "26 Shoemaker began by following a line of questioning that today would be considered standard: "Have you ever told anyone that you were a member of the Communist Party?"127 "Have you ever had occasion to deny that you are a Communist?"128 "Do you believe yourself in the teachings of the Communist Party, either wholly or in part?"129 In Bridges' three days in the witness chair, the

124. A Government lawyer was quoted as saying, "Being an alien, Bridges must answer all our questions as far as deportation is concerned, and there [sic] will include his affiliation with the Communist Party." Id.

125. The Government's new approach raised a problem of definition. An alien who was affiliated with the Party was as deportable as if he were a card-carrying, duespaying member. But what is affiliation? Landis followed the definition in United States ex rel. Kettunen v: Reimer, 79 F.2d 315 (2d Cir. 1935):

[Affiliation] is not proved unless the alien is shown to have so conducted himself that he has brought about a status of mutual recognition that he may be relied on to co-operate with the Communist Party on a fairly permanent basis. He must be more than merely in sympathy with its aims or even willing to aid it in a casual, intermittent way. Affiliation includes an element of dependability upon which the organization can rely which, though not equivalent to membership duty, does rest upon a course of conduct that could not be abruptly ended without giving at least reasonable cause for the charge of a breach of good faith.

Id. at 317 .

126. S.F. Examiner, Aug. 3, 1939, at 1, col. 1.

127. Angel Island Transcript 2474.

Bridges: "I have kidded people at times because it got to be such a joke on occasions, but soberly and officially I never have."

128. Id. at 2475-77. Bridges: "Plenty of times [if it is asked just to disrupt a union meeting] the question is ignored. At certain open forums where I believe the question is asked from a sincere desire to get the information, the question is answered."

129. Id. at 2481. Bridges:

I am not very familiar with the teachings of the Communist Party, only from a trade union point of view. . . . But the general question of, "Do I believe in the teachings of the Communist Party?" as far as I have delved into them, they are pretty much a matter of theory, and our hands are so full of practical matters that $I$ generally stay with the practical matters. 
prosecutor came back to this theme again and again, turning Bridges' social philosophy over and over, searching for a flaw. His answers, however, were of hittle help to the prosecution, indicating not much more than a distrust of some of the motives and policies of capitalism and a belief in the rights of workers. He claimed no real understanding of the underlying theories of communism, but felt the Party was, like himself, sympathetic to the rights of workers. ${ }^{130}$

To observers at the hearing, it was evident that Bridges was making a favorable impression on Dean Landis. His candor and forthrightness was like a salty breeze coming in off the Bay, clearing away the murk left by the prosecution witnesses. Arthur Eggleston, covering the hearing for the San Francisco Chronicle, summed up Bridges' appearance:

For those whio would like to keep Bridges a mythical monster and the labor movement something unknown and feared, the deportation hearing may turn out to be the worst thing that ever happened.

There are some supporters of Bridges who are a little fearful that he is being allowed by his own counsel to talk too much, to set forth with too great fullness and too little restraint his ideas on society, the State, industry, the labor movement, the relation of politics to labor, the relationship of the Communist Party and all others to the labor inovement. . . .

Against that is the view that the hearing, the probing of Dean Landis, the Government and the defense, and the full, unrestrained manner in which Bridges sets out his views is one of the best things that ever happened to the American labor inovement. ${ }^{131}$

\section{VIII}

The strategy of the defense, as it called its first witness, was as odd as that of the government in calling Bridges as a witness for the prosecution. It was Harper Knowles, who, logically, it would seem, should have been called by the Government. Knowles was, as he told the

Later, in reply to the same question, Bridges said:

It seems to me that it might be all very well to talk about taking over the means of production, but ... I ain not concerned with that. I beheve it will be 30 or 40 years hence, and $I$ do not think $I$ will be around. [There are plenty of things to be done today, for instance, the inatter of getting simple recognition of trade unions and so on. There are areas in this country and in this state where we do not dare go in as trade unions.]

Our entire struggle practically is carried on in trying to keep our rights to organize and to bargain collectively without going any further. I am not concerned with what is going to happen to the einploying class 30 or 40 years hence.

I atteinpted to wade through Marx's Capital. I didn't get very far. It seemed dry to ine.

130. See, e.g., Angel Island Transcript 2543-45; see also notes 127-29 supra.

131. S.F. Chronicle, Aug. 7, 1939, at 11, cols. 6-7. 
hearing, "one of the foremost people on the Pacific Coast who have been demanding a hearing against Bridges." 132

Knowles testified that his interest in radicalism began during the 1934 strike, when he was commander of the American Legion post in San Francisco. He and his Legion comrades, having persuaded themselves that Communists were behind the strike, organized a committee to keep the subversives under surveillance. After the strike, the committee, under Knowles' enthusiastic leadership, expanded rapidly. In no time, he had hundreds of informants all over the state sending in reports on individuals and organizations they believed radical. ${ }^{183}$

In 1935 and 1936, Knowles kept up a brisk correspondence with Frances Perkins, sending ler secondhand allegations and rumors that Bridges was a Communist; but, in 1936, he dropped this campaign in favor of a new tactic. Knowles, with Doyle and the Portland police, started looking for ex-Communists and anybody else they could get to swear that Bridges was a Red. This change, precipitated by Perkin's insistence on documented proof, ${ }^{134}$ not only produced the affidavits that resulted in Bridges' deportation hearing, but also destroyed the careers of at least two rival union officials who were induced into making untrue statements about Bridges. ${ }^{135}$

132. Angel Island Transcript 3133.

At the time of his appearance, Knowles was executive secretary of the Associated Farmers of California, an aggressively antiunion body that ostensibly rcpresented growers and processors but was actually a front organization financed by a cross section of California business up and down the state: the Industrial Association of San Francisco, public utilities, railroads, sugar refiners, oil companies, paper producers, can manufacturers, and so on. LA FolletTe COMMITTEE, REPORT, part V, at 74; LANDIs 51-52.

133. His committee became a clearing loouse for records and reports sent in from up and down the coast by a score of public and private agencies that were keeping an eye on union organizers and supposed leftists. Knowles testificd that he shared information reciprocally with employers and outfits like the Associated Farmers, but that his working arrangement with Army and Navy Intelligence, and with the immigration people, was one-way - he gave then information, but they didn't give lim any. Clarence Morrill, director of the California State Bureau of Crimmal Identification, was more cooperative, and Captain Hynes of the Los Angeles red squad carried out ad hoc investigations for Knowles. The teleplione company was helpful, too, releasing to Knowles phone numbers and addresses of people he wanted to get a line on. Angel Island Transcript 3167-73.

134. See note 14 supra. Knowles testified that at the 1936 Legion convention, a report, allegedly written by Charles Wyzanski (Reilly's predeccssor as legal adviser to the Labor Department), was circulated among the Legionnaires. It rcviewed Knowles' letters to the Secretary, advised her that what Knowles had submitted was worthless, and criticized Knowles' attitude as prejudiced and his language as intemperate and overbearing. LANDIS 51-52.

135. LANDIS 51-52. Besides Milner and Leech, who had testified at the hearing, the net thrown out by Knowles and Doyle produced such queer fisl as Ivan Cox, a former militant who had grown more conservative over the years, later breaking with Bridges over affiliation with the CIO, which Cox thought a Communist front. Cox was defeated for reelection as secretary-treasurer of the San Francisco longshoremen's local in 1937, and his successor found a shortage of $\$ 800$. Cox felt that he had been framed 
Knowles proved to be an effective witness for the defense, not so much because of what he had to say, but because, despite all his efforts, he had nothing of value to tell. The probative poverty of his appearance did not stem from reticence; on the contrary, he was quite talkative. It was because, as Landis said of him:

Knowles' relationship to the issues presented by this proceeding is not always clear. He was neither a candid nor a forthright witness. His inemory tended too frequently to become beclouded when answers might have proven to be too revealing. Recollection, even when it existed, tended at times to be suspiciously faulty. Because of these tendencies it becomes necessary on occasion to disbelieve him and also to treat a hesitant qualified admission tortuously wrung from him as far nore significant than would be the case with an open witness. ${ }^{136}$

If Knowles was the prime mover in the west coast effort to deport Bridges, the next witness, Police Captain Keegan of Portland was a close second. He was also an effective witness for the defense, and for the same reason as Knowles.

$\mathrm{He}$ is a trained police officer with years of service. Yet he swears falsely in behalf of Scott. His contradictions are both frequent and with regard to major matters, not in respect to minor uneventful details. He is required again and again to devise explanations, crude in character, when documentary evidence and other testimony di-

by Bridges, and, in his search for help, he discovered Knowles and Doyle. According to Cox, they suggested an elaborate plot, which included Cox's making an affidavit that he had been in a Communist Party meeting with Bridges and the filing of a conspiracy suit charging a Party plot to dominate the West through the unions, schools, and movies. Defendants were Bridges, the 13th district of the Conmunist Party, the San Francisco director of the NLRB, movie stars Frederic March and Mary Astor, and numerous Jane and John Does. See Statement of Ivan Francis Cox, Aug. 31, 1938, in Room 612, 216 Pine Street, San Francisco, in the presence of Richard Gladstein and Ernest Besig (on file in the ILWU archives in San Francisco). Before the suit reached trial, Cox signed another affidavit, repudiating both the affidavit about Bridges he'd given Bonham and the $\$ 5,100,000$ conspiracy suit. Id. "I told Doyle I didn't even know the movie stars and soine of the people named in the suit. But he told me, 'Don't worry about that. You're helping the Governnent, enabling it to construct its case around what you actually know.' " Interview with Henry Schmidt, July 10, 1964. (In 1958, when Schmidt was working for the La Follette Committee, he interviewed Cox about the incident.)

Another Knowles story involved John Ferguson, secretary of the nuarine firenen's union, which had been asked by AFL sailors for assistance in a dispute with the CIO longshoremen. Knowles and Doyle suggested to Ferguson that he give books in the firemen's uniou to a hundred out-of-work nien along the waterfront to ensure that he could get a majority of the firemen to go along with honoring the request. Bridges learned of the scheine and went to the firemen's meeting with 300 longshoremen and exposed it. Sixty or 70 men left immediately after Bridges announced that anyone with a forged book could leave the meeting in complete safety before he presented his proof. Thereupon, the membership rejected Ferguson's proposal and shortly thereafter expelled him from the union for 99 years. See generally Waterfront Bulletin, Sept. 17, 1937, at 1, col. 2; S,F. Chroniele, Dec. 8, 1938, at 5, col. 2.

136. LANDIS 51. 
rectly contradict his original recitals. He misled the examiner again and again only to be forced by documentary evidence and the testimony of others ultimately to reveal a wholly different story of his activities and the activities of his men than he first sought to portray. . . . . ${ }^{137}$

Keegan began by saying that his investigation of Bridges was routine, the kind he would run on a suspected housebreaker: "Bridges isn't any more to me than anyone else."138 He first became interested in Bridges, he said, when Larry Doyle called on him in 1937, just before a Maritime Federation of the Pacific Convention in Portland. Doyle told Keegan he was investigating Bridges for the state of Oregon, and Keegan loaned him Big Bill Browne, a member of the red squad and chairman of the Legion's Americanism Committee for his state..$^{130}$

Keegan said he decided that, while Browne and Doyle went off on their own, he had better cover the convention himself, with the help of several of his plainclothesmen. He had never done this with any other union meeting, but until the maritime workers organized, he hadn't had to worry much about unions. "We had a bitter experience during the 1934 waterfront strike because we weren't properly prepared .... I I wanted to know what was going on, and I couldn't find out much from the newspapers, especially what was going on in the caucuses." ${ }^{140}$ That seemed plausible, but later, under Gladstein's persistent questioning, Keegan admitted that he and his men hadn't paid any attention to strike talk. What they were after, he grudgingly conceded, was proof that Bridges was a Communist. ${ }^{141}$

If the Bridges investigation was routine, as Keegan insisted over and over, Portland police deserved high marks for industry. They were also unusually generous in the lengths they were willing to go to help the federal government, for the activities of Bridges that they concerned themselves with could only be prosecuted by federal authorities. But Keegan could not admit that he and his colleagues were an unofficial investigative arm for Government attorneys Bonhans and Norene, any more than lie could own up to his collaboration with Harper Knowles and the Los Angeles red squad. ${ }^{142}$ That would have con-

137. Id. at 69-70.

138. Id. at 56.

139. "I didn't have to give Browne any specific instructions when $I$ assigned him to work with Doyle, I had absolute confidence in Doyle's integrity and judgment. I still do." Angel Island Transcript 3548. Keegan greatly admired Sapiro, too, and had worked with him on the Bridges case. "I think he [Sapiro] is a wonderful man. I think more so now by his appearance at this hearing." Id. at 4340 .

140. Id. at 3542 .

141. LANDIS 56 n.65.

142. For example, Keegan had come down from Portland to witness the signing of Cox's anti-Bridges affidavit. Statement of Ivan Francis Cox, supra note 135. 
firmed the existence of the get-Bridges conspiracy that Carol King had pointed to in her opening statement.

Thus, Keegan was evasive when asked to describe why, for a couple of years, he and several of his men ranged up and down the coast, interviewing possible witnesses and following up leads for use against Bridges. Or the reason he put up the money to bring witnesses from Los Angeles and San Francisco to Portland so Bonham and Norene could talk to them. Or why the city should have paid the bill for his junket to Washington to testify before the Dies Committee that the Portland red squad had found Bridges to be a Communist.

All of this raised another sticky question for the squirming captam: Those trips had cost somebody a lot of money; where had it come froin? Keegan answered that his chief of police always met his requests for cash and never asked how he used it. He testified that not a dime came from outside the police department, but once agam, he had to recant. After repeated denials that he knew of any payments, he finally admitted that the teamsters' union, for one, had generously underwritten soine of his expenses, but that it had "shpped his mind."143

The next two defense witnesses, Harold Chapman Brown ${ }^{144}$ and Walter Thompson, both professors at Stanford, were called to testify about Marxist theory and thereby to counter the Government's contention that the Communist Party advocated the violent overthrow of the Government. ${ }^{145}$

143. LANDIS 64-66, 69. Keegan's denial of outside assistance, moreover, hurt the feelings of one of the donors, an official of the teamsters' warehouse local in Portland.

I personally would contribute money right today towards any fund to investigate anybody that was a Communist, providing they are a Communist. . . . And why Captain Keegan should take the witness stand and swear under oath that he didn't receive any money froin me is beyond my coinprehension. If I was Captain Keegan, I would be very proud of the fact that there was money paid in by citizens that were willing to do these things.

Id. at 68. This he said overlooking the fact that it had been the union's money he had given Keegan, not his own.

144. Brown, an old-fashioned scholar, clained a reading knowledge of Latin, Greek, French, and German. He could read Italian and Russian too, he said, with the help of a dictionary. An admirer of John Dewey, Brown's interest in Marx had grown out of his discovery of similarities between Dewey's concept of levels and Marx's dialectical inaterialism. Once interested, he had plunged on to read the 15 volumes of Lenin's work. Angel Island Transcript 4344-49.

145. Id. at $4343,4354,4566$.

Harry wasn't sure it was a good idea to get into the question of Communism. He wasn't sure how the rank-and-file in the union would react if we put witnesses on the stand for that purpose. "They may get the idea we're defending Communism rather than me." We debated for quite a while, but fimally we convinced him that you might look hike a Red if you defend Communism, but we'd better take that chance. What if some fink's testimony convinces Perkins, we argued, that you've been in the Party? If we haven't challenged the Governinent's contention about the Party, you're as good as gone.

Grossman interview, supra note 59. 
After Knowles, Keegan, and the professors, the next witness was, in a way, a relief, though he was not of much value to the defense. It was Charles C. Bakscy, ${ }^{146}$ who told an entertaining story of his experiences as a private detective and of how he was hired by T.G. Plant of the Waterfront Employers' Association to get the goods on Bridges. The assignment took him to Carmel, the artists' and writers' colony down the coast from San Francisco, where Lincoln Steffens, the noted muckraker and admirer of the Soviet experiment, lived with his wife, Ella Winter. In her autobiography Miss Winter has explained why Bakscy was dispatched to Carmel:

Someone had sold San Francisco industrialists on the idea that "all the noney"-for the waterfront troubles, the maritime strike of thirtyfive, the general strike, the "agitation" in the agricultural fields for higher wages-came from Moscow, that the Soviet Consul brought it to Carmel, and Stef gave it to Harry Bridges. ${ }^{147}$

Steffens, a boxing buff, was an easy nnark for Bakscy, who introduced himself as Young Sliarkey when he called on the writer carrying copies of Steffens' Autobiography and Red Virtue, to be autograpled. With Steffens as his sponsor, Bakscy was soon moving in the galaxy of liberals, radicals, Hollywood movie stars, and writers that revolved around Steffens. Bakscy rented a large beach house, fitted it out with hidden microphones and cameras, and launched a series of large parties where the liquor never seemed to run out. Talking like a radical, lie soon liad a bulging file of quotes from his guests whom he entrapped into discussing "the coming revolution."148

Bakscy worked closely with Knowles and Doyle and their coast-

146. Angel Island Transcript 4704-06.

When the bailiff called him to the stand, he gave his name as Captain Bakscy. Aubrey Grossman, intrigued by the witness' appearance-he was a short, stocky man with a broken nose, cauliflower ears, a Van Dyke moustache and beard-asked, "Where did you get the term, 'Captain'?"

"I was captain of the four-masted bark Lisbeth, a big sailing ship," Bakscy answered. Going on to explain that he had been a sailor on the vessel and that, as they were rounding the Horn in a furious storm, the ship began to leak. The real captain, convinced the ship was lost, went below and brought up rum so that all hands could go down happily. He and his first mate drank themselves into a stupor, but Bakscy and a few others stayed sober. "We took charge of the ship, us sailors, and tied the captain of the boat and sailed her to the Falkland Islands, and from there we took her to London, England." Id. at 4704.

Bakscy also testified that he had been a professional boxer, fighting as Young Sharkey, and a professional wrestler, under the name of Strangler Schmidt. He had been asked to shanghai sailors. His greatest triumph as a private eye, he testificd, was when he wormed his way into a job in the office of Big Bill Haywood, chief officer of the IWW, while at the same time he was on the payroll of General Leonard Wood's intelligence bureau, reporting on Haywood's activities. Id. at 4705, 4708, 4710.

147. E. WINTER, AND NoT To YIELD 207-08 (1963).

148. Id. at 208-09. 
wide espionage network. His relationship with them was never comfortable, he said, for they nagged him persistently to turn up something they could use against Bridges. ${ }^{149}$ He broke with them when they threatened to go to the waterfront employers and get him fired unless he would perjure himself by signing a statement that Bridges was at a meeting at Steffens' house when Bakscy knew that he was not. ${ }^{150} \mathrm{He}$ further testified that while he was on the Carmel assigninent he was, of course, reporting regularly to the waterfront employers in San Francisco, but he never was able to get anything they could use against Bridges, and after about six months, they cut him off..$^{151}$

With the next several witnesses, the hearing assumed a more dramatic character. The defense wanted to call Earl King and Ernest Ramsay to show the lengths to which Knowles, Doyle, and Bonhain had been willing to go im their effort to get Bridges. King and Ramsay were in San Quentin Prison ${ }^{152}$ and could not come to Angel Island, so Landis solved the problem by taking the hearing to the prison. ${ }^{153}$ But before that, the defense had three other witnesses it wanted to call.

The first was Garfield King, Earl's brother, sixtyish, respectable, and a successful solicitor and barrister in Vancouver, British Columbia. He testified that one day im February 1938, he was asked to call on an American named Shearer, a U.S. Immigration Service officer stationed in Vancouver. Shearer had just received a letter from his boss, Raphael Bonham. In the letter, Bonham said he had discovered that there

149. LANDIS 74.

150. Id.

151. Angel Island Transcript 4718.

152. In 1936, during a campaign to organize marine firemen, George Alberts, a chief engineer who had been fighting the uniou, was found knifed and beaten to death in his cabin on the ship Point Lobos, while it lay at anchor at Oakland. Three officials of the marine firemen's union, King, Ramsay, and Frank Conuor, were charged with conspiring to hire a pair of goons to (in waterfront jargon) dump him. Earl Warren, the district attorney, charged that the goons did their job too well and Alberts died. Warren publicly proclaimed King to be "the Communistic leader of the Marine Firemen's local union." S.F. American Labor Citizen, Sept. 12, 1936.

Like the case of Mooney and Billings [C. GENTRY, FRAME-UP (1967) is a good treatınent of the Mooney-Billings case], the King-Ramsay-Connor affair became a cause célèbre in labor and hiberal circles on the coast, but the three men were convicted and sentenced to five-years-to-life.

However, in 1942, after the men had been in prison five years, Governor Olson commuted their sentences to time served. Connor went back to sea, Ramsay went back to his job as port agent for the firemen's union in Sau Francisco, and King became a liceused marine engineer and an official of the marine engineers' union.

153. LANDIS 2 n.12. Landis did not explain in his report why King and Ramsay could not respond to the subpoenas at Angel Island, saying only that he was advised they could not do so. Id. The San Francisco Examiner reported, liowever, that the warden of San Quentin had asked California State Attorney General Earl Warren if King and Ramsy could be taken from the prison to Angel Island to testify and that Warren had ruled they could not. S.F. Examiner, Aug. 26, 1939, at 11, col. 7. 
was some doubt about Earl King's guilt. If Garfield could help persuade his brother to make out an affidavit establishmg that Bridges was a Communist, Mr. Bonham might be able to use his influence with certain judges. ${ }^{154}$ The proposal struck Garfield King as a dishonorable one, and he refused to cooperate; indeed, he thought Shearer felt the same way. ${ }^{155}$ The Government did not challenge King's testimony. ${ }^{156}$

Next Gwendolyn Ramsay, Ernest Ramsay's 18-year old wife, told a similar story. Doyle had approached her, saying that if she would sign a statement placing Bridges at a Communist Party meeting, Doyle would use his influence to obtain her husband's release. ${ }^{157}$ After her refusal, Gwendolyn's mother and Ernest Ramsay himself were approached with similar propositions, but they too refused. ${ }^{168}$

Shoemaker, visibly shaken by Mrs. Ramsay's story, had no questions upon cross-examination. "I couldn't question you," he said to her durmg the next recess. "You've had enough trouble in your young life, without my adding any more."150

Before the hearing moved over to the prison, the defense sandwiched in a character witness, Dean Wayne Morse of the University of Oregon law school. Morse, describing himself as a progressive Republican (at the time, Oregon was a one-party Republican state), testified that in 1938, after he had been doing ad hoc labor arbitrations for several years, Secretary Perkins appointed him arbitrator ${ }^{100}$ for the longshore industry in the Columbia River area. In January 1939, she promoted him to the top arbitration position for the west coast, where he reviewed appeals from decisions of port arbitrators below. At the same time, she gave him the added responsibility of arbitrating disputes in the coast's trouble spot, the San Francisco Bay Area.

Bridges had been involved in 30 to 40 arbitration proceedings

154. LANDIS 73.

155. Id. King made notes on the conversation and embodied them in an affidavit.

156. Landis' comment on this episode was caustic.

[Garfield King's testimony] was given in the presence of Bonham, and thus the Government thereafter had ample opportunity to rebut it. No such effort was made, the Government contenting itself with the argument that, inasmuch as Garfield King admitted that it was not suggested to him explicitly that he should urge Earl King to testify falsely, the action of Bonham could not be Id. truly criticized.

157. Id. at 71 .

158. Id. Mrs. Ramsay accompanied Doyle to San Quentin when he went there to see her husband. She noticed that Doyle seemed to know the guard at the gate, and did not have to sign a visitor's card. Angel Island Transcript 5761-62. But, as Landis observed in his report, "visitors' slips were obviously not too carefully kept." LANDIS 72.

159. WARD 200.

160. Angel Island Transcript 5731. 
Morse had presided over, and Morse therefore knew Harry Bridges well, though he had not had any social contact with Bridges. ${ }^{161}$ Grossinan, who was questioning Morse, hoped to get into the record a statement from him that in his opinion Bridges was honest and trustworthy. Landis ruled that Morse could not make such a statement because it would be opinion, not fact, ${ }^{162}$ but he allowed a statement that Morse knew from his own observation and from talks with waterfront workers that among the longshoremen Bridges had a reputation for being truthful. ${ }^{163}$

Perhaps because Morse was a fellow law school dean (Oregon), Landis felt that during his testimony he should be meticulous in the application of evidentiary rules. Thus, Grossman was not allowed to ask, "Have you observed any conduct on the part of Harry Bridges as either a witness or as an advocate in any of these arbitration proceedings which would cause you to conclude that he is a member of the Communist Party?"164

But he was allowed to ask,

Is there anything about the position taken by Harry Bridges, either as a witness or as an advocate before you, which could cause you to draw the conclusion that he [is] a member of the Communist Party?

……

No. ${ }^{165}$

161. Id. at 5733.

162. Id. at 5736 .

163. Id. at 5741 .

164. Id. at 5749. Landis:

That is a matter of opinion. ... If you want to ask whether the witness knows any facts which are relevant to the issue, I have no objection to that. Grossman:

I would like to make this plain. Obviously, $I$ am not asking this question of the witness as a character witness, but .... [t]here is plenty of testimony in the record, based on no facts whatsoever. For imstauce, there has been evidence offered that Harry Bridges is a Communist based on his conduct, and nothing else. If that evidence is relevant on one side, it should be on the other.

Landis:

There is testimony in the record that he is reputed to be a Communist, a great deal of that type of testimony. There is testimony to the effect that a witness says, "I know him to be a Communist," and when the basis of that knowledge is examined in a particular instance it may turn out that the basis for the witness' inference in that particular case has been the fact that Mr. Bridges supported a particular motion, we will say, to picket the German Embassy or something of that nature. What is purported to be knowledge in some of these situations has been knowledge based upon an inference drawn from items of that type.

Now, if you want to ask the witness what knowledge he has upon which he would indulge an inference that he is a member of the Communist Party, or that he is not a meinber of the Communist Party, what facts he can testify to along that line, I think that is relevant.

Id. at 5749-50.

165. Id. at 5750 . 
The day the hearing party sailed over to San Quentin was warm and cloudless, as if to intensify the somber purpose of their trip. For a hearing room, the warden let them use the auditorium of the prison guards' recreation building. After lunch, he invited everyone on a tour of the prison. The main attraction was San Quentin's sinoke house, as prison inmates called the gas chainber. They all went, except Bridges and Carol King, who waited for the others on the recreation hall steps. "It's too morbid," Bridges said, as the warden led the others away. ${ }^{106}$

Ernest Rainsay, testifying first, said that Doyle had told him, "I am connected with the governor's office in California here, Governor Merriam's office, and with the immigration department. We have an affidavit here we want you to sign."167 He refused, saying he had no evidence that Bridges was a Communist.

Earl King was the next witness. He testified that when Doyle approached him he did not know who he was, but at first thought he was "just another attorney looking . . . to get a job on my case."108

"I was the prosecutor in the De Jonge case," Doyle told him (King hadn't heard of it), flashing his gold State of Oregon special agent's badge. "Now, I want you to get Mr. Bridges out of the country. I have connections with the right people, and if you'll give testimony that you sat in top fraction meetings with Bridges, in places and dates I'll give you, I'll see that you get out." Without hesitation, King told Doyle he wouldn't do it. According to King, Doyle was unable to understand King's refusal and kept after him, threatening him, as he had Ramsay, with being framed for another inurder. ${ }^{100}$

When Doyle got up to go,

he shook hands with me and started off, and he turned back, and he says, "Say, what has Bridges got on you?"

I says, "Bridges hasn't got anything on me."

"Well," he says, "what is the matter with you?"

"Well," I says, "I told you. I am not going to lie," I says, "against Harry Bridges just to get out of here." I says, "I don't care what happens to me now," I says, "I have only got my self-respect left; I am going to keep that. Nobody is going to take it away."170

\section{IX}

The hearing was starting into its ninth week when Landis declared a holiday to allow Bridges to march in the Labor Day parade.

166. S.F. Examiner, Aug. 26, 1939, at 11, col. 8.

167. Angel Island Transcript 5786-87.

168. Id. at 5853-54.

169. Id. at 5856-58.

170. Id. at 5860 . 
It was a magnificent affair; 30,000 CIO marchers, with Bridges at their head, paraded up Market Street from the Ferry Building to the civic center. Just behind Bridges were 8,000 longshoremen, eight abreast, stretching back farther than the eye could see, all wearing the dockworkers' uniform-white caps, hickory shirts, black Frisco jeans. ${ }^{171}$ At the civic center, Bridges' theme was AFL-CIO unity: "Despite certain differences, we know that basically, the objectives of labor unions are the same, and that eventually we will all agree together."172

AFL unions held a separate meeting on Treasure Island, out in the Bay, where San Francisco's Mayor Rossi told them that their organization, unlike, by implication, the CIO, had the respect of the American people. Then, without specifying whom he was referring to, he launched into an attack on "subversive influences in labor, radical and un-American leaders, and outright Communists."173

In the last week of the hearing, Landis listened to half a dozen more defense witnesses and twice that many put on by the Government in rebuttal. The most interesting was Major General David Prescott Barrows, called by the Government as an expert on communism to rebut the testimony of the two Stanford professors.

Barrows was a formidable witness. "Gray, a perfect picture of a military gentleman of the old school," Harry Lang described him in the San Francisco Examiner.

He knows Communism, he knows Marxism, he knows Leninism-not only as a pure theorist, as the Stanford professors who testified for the defense, but also from the practical side, as a man who encountered it on its own chosen field-the bloody field of violence! ${ }^{174}$

171. S.F. Chronicle, Sept. 5, 1939, at 12, col. 2.

172. Id. at cols. 2-3. Sharing the platform with Bridges was California's New Deal governor, Culbert Olson, who talked of the ueed to liberalize social security, to achieve the widest public ownership of water and power resources, to give the poor a better break under the tax system, and to establish a one-house legislature in California "because the Senate is an undemocratic institution."

173. Id. at col. 4 .

174. S.F. Examiner, Sept. 9, 1939, at 12, col. 6. Barrows had had an extraordinary military career. In 1911, he was in Mexico with the Madero forces. During World War $I$, he was in military intelligence, which sent him to Siberia during the Russian Revolution to make au estimate of the military situation there. After the Russians signed the treaty of Brest-Litovsk early in 1918 and pulled out of the war, he regarded the Bolsheviks as an enemy because their leaving the war aided Germany. Angel Island Transcript 7418. Then, when the American-British-French-Japanese Expeditionary Force invaded Siberia to help the White forces put down the Bolsheviks, Barrows acted as assistant chief of staff in the intelligence section.

Liking military life, he kept up his connections with the army after the war. In 1934, be comnianded the guardsmen sent to the waterfront during the longshoremen's strike, was a Brigadier General of the Line, a Major General of the Army, commissioned by the President, aud a Major General in the National Guard, commissioned by the Governor. 
Barrows was more than just a military man. He was also a professor of political science at the University of California, where he had been president from 1919 to $1923 . .^{175}$ And in the academic year 1933-1934 he had taught political science at the University of Berlin.

Barrows' testimony on Angel Island consisted of a long lecture, which he gave without a prepared manuscript, on Marx, Lenin, and the theory and practice of communism. When he fmished, Landis summarized Barrows' view of Communist tactics as consisting of three steps: First, softening of the mechanism of the state, by causing disaffection in the armed forces, for example; second, taking advantage of some crisis such as defeat in war or a severe economic depression; and third, taking over the state as the opportunity arises. ${ }^{170}$

"Would you say," Grossman asked, "that such a thing as a general strike, in the setting that it occurred in 1934, was part of the softening-up process that you have been discussing?"

Well, no. I would say that a general strike . . . was a poor instrument to use for the softening-up process, because it invariably irritates and prejudices public opinion.

But I would say that the general strike, if one is to be called, should be the immediate prelude to the supreme act of violence itself, the seizure of political power, and if it is called prematurely, why, your Communist leadership, your Communist general staff, have just made a mistake, as I think they made in San Francisco. ${ }^{177}$

175. Angel Island Transcript 7418. In 1965, Barrows Hall, a new building for the social sciences, journalism, and business was named for him.

The professor seems to have been preoccupied with Communism. See the report of a speech he delivered to the American Legion three weeks before he testified at Angel Island, in S.F. Chronicle, Aug. 16, 1939, at 7, col. 1. In 1934, he wrote a manual for the California Peace Officers' Association on comnunism and how to deal with it. Federal Laboratories, a munitions company, helped finance the publication, presumably to stimulate sales of their industrial munitions. La Folletre CommitteE, Hearinos, P. 15-D, at 7017-18.

176. Angel Island Transcript 7425.

177. Id. at 7439. Bridges' attorneys put another line of questions to Barrows, asking him if he knew a White Guard General named Senreonoff, knew that officers of the 27th U.S. Infantry had sent in reports criticizing Semeonoff for unnecessary brutality, and still consented to testify for Semeonoff at a hearing to determine if he should be denied entry to the U.S. as an undesirable? Barrows answered yes to all these questions, explaining that

the war methods of Semeonoff were extrenely rough, were repugnant, but they were no more repugnant than the war nuethods of almost any other military commander on either side engaged in the higlily irregular warfare that went on in Siberia during the period that $I$ was there.

Id. at 7423.

The defense did not pursue this line of questioning, but one might hope that General Barrows erred in his estimate of Semeonoff's methods as typical. Major General William S. Graves, who commanded the American forces in Siberia, refers to Semeonoff in his book about the Siberian expedition as "a murderer, robber, and a most dissolute scoundrel." W. Graves, AmericA's Siberian ADVENTURE 86 (1941). Indeed, reading 
On September 11-two months, almost to the day, from when the hearing began-Landis observed that Doyle had wired that he was on his way to San Francisco, ${ }^{178}$ but it would be several days before he could get there. Landis also announced that school was reopening and he would have to return to Harvard, but that John G. Clarkson, an old friend from the Securities and Exchange Commission, would preside over the hearing when Doyle arrived. ${ }^{179}$

Heading back to Harvard and the relative calm of the campus, Landis could look back with pride on his two months in San Francisco. $\mathrm{He}$ had presided over a hearing which in other hands could easily have degenerated into a kangaroo court. But he had withstood the temptation to follow what was virtually a tradition in American political

Graves, the feeling is inescapable that as he thought back over his experiences when he was writing the book in 1930, he was still choking with rage at the memory of having been on the same side with Semeonoff. Sprinkled through his account are a half-dozen grisly descriptions of atrocities carried out under the personal direction of the general.

One was

the almost unbelievable murder of an entire village by Semeonoff. When his troops reached the village, the inhabitants apparently tried to escape by fliglit from their homes, but the Semeonoff soldiers shot them down, men, women, and children, as if they were hunting rabbits, and left their bodies where they were killed. They shot, not one, but everyone in the village. [They found] four or five bodies of men who had evidently been burned alive.

Id. at 246 .

As the campaign against the Bolsheviks progressed, Graves reported, "Semeonoff established what were known as his 'killing stations' and ... openly boasted that he could not sleep at night when he had not killed someone during the day." Id. at 241.

Inevitably, Americans clashed with Semeonoff when his pursuit of Bolsheviks carried him into areas U.S. soldiers were responsible for. On one of these forays, be was so enraged when U.S. soldiers guarding a railroad depot refused to turn the stationmaster over to hin that he ordered his men to shoot up their 38-inan outpost in the middle of the night. Happily, his troops were less accurate against targets who could shoot back than against unarmed peasants. Semeonoff's raiders were repulsed with heavy losses, while the Americans suffered only two casualties-one killed and one wounded.

178. LANDIS 141. Doyle had been in the news the day Bakscy testified. It was the duty of the federal marshal in St. Paul, Minnesota, to arrest him and ship him out to Angel Island, because he had been ignoring the order of a federal court to appear at the hearing. But for some reason the marshal hadn't seemed able to find him. Reporters assigned to the case thought this a bit odd, for they had no trouble finding him at all. One, taking a photographer along, went to the American Legion convention in Minneapolis, just across the river from the marshal's office in St. Paul, and sure enough, there was Doyle, chatting with his coinrades. He lightheartedly posed for a picture, freely admitting that he was dodging the subpoena. He was going to keep on doing so, he added, as long as it was the defense that wanted him. "It's obvious what Bridges's lawyers are up to. They want to get me on the stand and get all of my evidence, and then they'll bring in a troupe of witnesses who'll deny every statement I make." Then he added, as if he were under the impression that they couldn't do that if he were a witness for the prosecution, ' $\mathrm{I} m$ willing to come out voluntarily if the government wants me to testify." S.F. Chronicle, Aug. 17, 1939, at 1, col. 2.

179. LANDIS 141. 
trials. Instead, as a San Francisco newspaper said editorially after he left:

Both the prosecution and the defense paid tribute to Dean James M. Landis for his conduct of the Harry Bridges Deportation inquiry. They agreed that he gave a full and fair hearing. . . .

A man of Supreme Court caliber, he brought to the hearings a rich philosophy of what American justice means, he held both sides to the issues and he was eminently fair..$^{180}$

Although Doyle's testimony was eagerly awaited, his presence in San Francisco proved anticlimactic. His first day at the hearing he refused to testify unless his travel expenses were first paid in full. After seemingly endless haggling, the defense agreed; then, however, he demanded that the hearing be completely open to the public during his testimony, contrary to Landis' previous orders. Thus, it was necessary to get an order from the federal district court commanding him to testify, ${ }^{181}$ and still, when the hearing reconvened, he refused to testify, arguing over the meaning of the order. In the end both the prosecution and the defense agreed that his testimony was not really necessary and he was excused. ${ }^{182}$

Whereupon at 4:30 F.m. on September 14, 1939, the hearing was concluded. ${ }^{183}$

\section{$\mathrm{X}$}

The 91/2-week hearing produced some impressive statistics. The Government called 32 witnesses, the defense, 29 (30, if you count Doyle). The Government put in evidence 138 exhibits, the defense, 136. Interrogation of witnesses by Bridges' attorneys filled 4,324 pages of the 7,724-page transcript, interrogation by lawyers for the Government another 2,900, and Landis' questions and comments took up the remaining 500 .

How much this cost the taxpayers is anybody's guess, but in November, Bridges' defense committee pubhished the results of an

180. S.F. News, Sept. 13, 1939, at 14, col. 2 (editorial).

181. Landis had decided against admitting the press when Doyle testified:

[Landis] also concluded that inasmuch as Mr. Clarkson's duties were to be limited to those of a presiding officer, having no duty to find the facts, that the testimony of Doyle should not be taken publicly but rather by way of deposition. This testimony upon its conclusion would be forwarded to the examiner and by him be made a part of the public record.

LANDIS 141. Doyle's attorney argued that Doyle had a right to an open hearing and refused to let his client testify as Landis prescribed except under court order. Angel Island Transcript 7657. The court order was soon obtained, but there was then more haggling over expenses. Id. at 7724.

182. Angel Island Transcript 7718.

183. Id. at 7724 . 
audit of its books showing a surplus. The committee had received $\$ 32,253.13$ in contributions and spent $\$ 28,424.16$, winding up with a surplus of $\$ 3,828.97$, which it turned back to the longshoremen's locals. Legal costs were $\$ 16,322$, publicity $\$ 6,476$, administrative expenses $\$ 5,625 .{ }^{184}$ A lot of money, but peanuts compared to what Bridges' next three trials were to cost. And a bargain price for the quality of legal service he'd had.

When Landis left San Francisco in September, he estimated that he would file his report around November 20. He was much too optimistic: it took him, not one inonth, but more than two. When it was published by the government printing office in its final form, it was a medium-sized book of 152 pages. He sent it to Secretary of Labor Perkins on December 28.

If Perkins had had any doubt about Landis' conduct of the case or about his findings-or if she had lacked courage to face the storn of criticism-she could have taken refuge behind a board of review in the immigration service. However, she did not lack courage, nor, havimg read Landis' report, did she have any doubt as to what she should do. On December 30, 1939, she announced Landis' findings: "The evidence . . . estabhished neither that Harry R. Bridges is a member of nor affiliated with the Communist Party of the United States of America." 185

\section{XI}

The case of the Government against Bridges should have ended there, of course. But political cases die hard, whoever loses. Shrill cries of protest against Landis' decision filled the air on Capitol Hill, culminating in a change in our immigration law, under which the Government could deport an alien if he had ever been a Communist. ${ }^{186}$ And in case anyone was in doubt about the purpose of the new statute, its sponsor gave his colleagues the word on what it meant:

It is my joy to announce that this bill . . . in a perfectly legal and constitutional manner . . . changes the law so that the Departinent of Justice should have hittle trouble in deporting Harry Bridges. . . . ${ }^{187}$

Armed with its new power, the Justice Department, which early in 1940 had inherited the Immigration Service from the Labor Departınent, leveled a new attack on Bridges. This time, it employed

184. Audit of the Harry Bridges Defense Committee, Nov. 1939 (on file at I.L.W.U. Library, San Francisco, Cal.).

185. LANDIS 134.

186. The Alien Registration Act of 1940 (Smith Act), 8 U.S.C. $\S 137$ (g) (1970).

187. 86 Cong. Rec. 9031 (daily ed. June 22, 1940). 
another formidable weapon, the FBI, whose director, J. Edgar Hoover, spent a week in San Francisco making sure the investigation was properly launched. Three inonths later, when Hoover made his report to the Attorney General, he leaked its conclusion to the press: "Our investigation shows beyond a doubt that Bridges is a Red."188

A new hearing was held, and this time Bridges was found to be deportable. (Interestingly, none of the witnesses the government had paraded before Dean Landis was used in this second hearing. ${ }^{180}$ ) However, the hearing officer's ruling was unanimously rejected by the Immigration Service's five-member review board, ${ }^{100}$ but the board in turn was overruled by Francis Biddle, then Attorney General. Before making public his decision, Biddle wcnt to the White House to tell the President what he proposed to do. We were now in World War II, on the same side as the Russians, and they might not like it, Biddle thought, if we deported a man because he was a Communist:

I did not ask his advice, but spoke in some detail of the reasons for iny action. He whistled, drew deeply on his cigarette, and for a moment was concentrated in thought. "I'm sorry to hear that," he said. Then his face cleared; he screwed the butt of his cigarette in the ash tray. "T'll bet," he said, "that the Supreme Court will never let him be deported." Then he said with a smile, "And the decision is a long way off." "101

F.D.R. knew his Court. The war was almost over when the decision came down. ${ }^{102}$ The opinion, written by Justice Douglas on behalf of himself and four other Roosevelt appointees, held that in finding Bridges deportable, the Government had relied on evidence too weak and witnesses too doubtful. Douglas' indictment of the Governinent was forceful, but not strong enough for Justice Murphy, who wrote a concurring opinion:

The record in this case will stand forever as a monunent to man's intolerance of man. Seldom if ever in the history of this nation has there been such a concentrated and relentless crusade to deport an individual because he dared to exercise the freedom that belongs to him as a human being and that is guaranteed to him by the Constitution.....193

When the immutable freedoms guaranteed by the Bill of Rights

188. F. BIDDLE, IN BRIEF AUTHORITY 297 (1962).

189. Landis commented on this in 1963, in his oral history menoir: "You know, in all these subsequent trials of Bridges, one amusing thing was, no witness that was ever called before ine ever appeared again. The government never dared to call them." Landis interview, supra note 54.

190. Board of Immigration Appeals, supra note 14.

191. F. BibDLE, supra note 188 , at 302.

192. Bridges v. Wixon, 326 U.S. 135 (1945).

193. Id. at 157 . 
have been so openly and concededly ignored, the full wrath of constitutional condemnation descends upon the action taken by the government. ${ }^{194}$

Bridges, you might say, had surely had enough due process by now; but more was to coine. Five years later, in 1950, Bridges was again in court, this time charged with having criminally conspired with his two witnesses to obtain his citizenship by perjury. ${ }^{195} \mathrm{He}$ and his witnesses lied, the Government contended, in response to the judge's question about inembership in the Party.

The trial opened a few weeks after Senator Joseph McCarthy's speech in West Virginia accusing hundreds of State Department elnployees of being card-carrying Communists. ${ }^{106}$ To represent him, Bridges selected Vincent Hallinan, a native son of San Francisco and a successful criminal lawyer who had never before participated in a political case. After taking the case, Hallinan read the transcripts of the first two hearings. ${ }^{197}$ Every witness against Bridges in those hearings, he noted, had been impeached. "The trial," he said to himself, "will be a breeze." When it was over, he was a disillusioned man:

In dealing with many agents of the U.S. Government, you must assume, until the contrary is completely established, that these representatives might commit felomes, suborn perjury, conceal evidence, bribe witnesses, intimidate jurors, convey information to judges, and otherwise engage in practices which would be the cause for disbarinent or imprisonment for a private attorney. ${ }^{198}$

He might have added that when the country is reeling from an acute seizure of anti-Communism, a judge will send you to jail for contempt if, in your opening statement, you try to review the two previous hearings and say what Justices Douglas and Murphy had to say about the Bridges case.

It was probably inevitable that Bridges would be convicted-McCarthyism was in full cry, the Korean War underway-but once again,

194. Id. at 160 .

195. The Court's decision had come down on June 18, 1945. On June 23, 1945, Bridges had filed the preliminary form for a petition for naturalization. On August 8, 1945 , he testified at a hearing before a naturalization examiner, Lloyd Garner. On September 17, 1945, he appeared with two witnesses in superior court im San Francisco. The following colloquy ensued:

The Court (to the Examiner): "Do you have any further questions?"

Mr. Garner: "The government has no further questions."

The Court: "Well, do you have any objections?"

Mr. Garner: "No objection your Honor."

United States v. Bridges, 133 F. Supp. 638, 640 n.3.

196. R. ROVERE, SENATOR JOE MCCARTHY 124-25 (1959).

197. V. Hallinan, A Lion IN Court 242 (1963).

198. Id. at 230 . 
in 1953, the Supreme Court came to his rescue, ${ }^{109}$ ruling that the 3-year statute of limitations barred the trial.

Having struck out in its first three "trials," in 1955 the Government brought a fourth action against Bridges. This time, the charge was civil conspiracy. His lawyer was Telford Taylor, and the trial was heard before federal judge Louis Goodman, without a jury. By the standards of the other actions, this one was short, lasting only a month. The attitude of the judge, moreover, even though the McCarthy era was not yet over, harked back to Dean Landis rather than to the presiding officers in the second and third proceedings.

To cancel [Bridges'] citizenship, after ten years of presumptively good and proper citizenship, the government had to meet an exacting standard. Particularly is this so after abortive efforts to prove the same issue in different proceedings . . . . 200

When all the testimony was in, the Government had struck out again. Judge Goodman concluded:

The inherent infirmity of the government's case lies in its own evidence and does not manifest itself out of any conflict between the opposing witnesses. . ..201

Only a weak yielding to extra-judicial clamor would excuse acceptance of the testimony of the witnesses in this case as proof of the allegations of the complaint. ${ }^{202}$

Once again, Judge Goodman's acquittal seemed to end the Bridges case. But whatever else you might say about our federal government, it deserves, like the Portland red squad, ${ }^{203}$ high marks for perseverance.

They've never really given up on Harry . . . . [T]hey passed a section of Landrum-Griffin ${ }^{204}$ that made it a crime for a man to hold union office if he'd been a Communist within the past five years. Archie Brown ran for the local (longshoremen's union) executive board to test it, with Harry's support.

If the Brown ${ }^{205}$ decision had gone against us [Brown's conviction was reversed in a 5 to 4 Supreine Court decision in 1965], then they'd have gone against Harry. There's a sentence in Sec. 504,208 you know, that says: "No labor organization or officer thereof shall

199. Bridges v. United States, 346 U.S. 209 (1953).

200. United States v. Bridges, $133 \mathrm{~F}$. Supp. 638, 643. At the end of his decision, Judge Goodman appended a chronology of Bridges' naturalization proceedings, hearings, and trials-from 1921, when Bridges first filed papers for naturalization, through the 1953 Suprene Court reversal of his 1950 criminal conspiracy conviction.

201. Id. at 642 .

202. Id. at 643 .

203. See note 143 supra and accompanying text.

204. Labor-Management Reporting and Disclosure Act, 29 U.S.C. \& 504 (1970).

205. United States v. Brown, 381 U.S. 437 (1965).

206. Labor-Management Reporting and Disclosure Act, 29 U.S.C. $\$ 504$ (a) (1970). 
knowingly permit any person to assume or hold any office or paid position in violation of this subsection."207

Paranoid? The lawyer's remark took me back to a meeting of the ILWU executive board in 1962, which I attended as an observer. When the meeting convened after lunch, Bridges held up a letter he had just received from the U.S. Attorney General, saying, "I'm going to read this to the board not because I'm worried about it, but so you'll know about it if anything ever comes of it. I've already sent a copy over to our lawyers."

Dear Mr. Bridges: We note that Archie Brown has been convicted of violating Sec. 504 of the Labor and Management Reporting and Disclosure Act of 1959 . We thought we'd call your attention to the fact that if he loses his appeal, you may be prosecuted for violation of the Act. You knowingly supported him when he ran for office. . . . .208

Did the Old Left get due process?

207. Richard Gladstein, interview with the author, in San Francisco, April 1967. ing.

208. From notes taken by C.P. Larrowe at a 1962 ILWU executive board ineet- 